\title{
Motivational strategies and approaches for single and multi- player exergames: A social perspective
}

\author{
Gerry Chan ${ }^{\text {Corresp., }}{ }^{,}$, Ali Arya ${ }^{1}$, Rita Orji $^{2}$, Zhao Zhao ${ }^{3}$ \\ ${ }^{1}$ Carleton School of Information Technology, Carleton University, Ottawa, Ontario, Canada \\ 2 Faculty of Computer Science, Dalhousie University, Halifax, Nova Scotia, Canada \\ 3 Department of Systems and Computer Engineering, Carleton University, Ottawa, Ontario, Canada \\ Corresponding Author: Gerry Chan \\ Email address: gerrychan@cmail.carleton.ca
}

Background. Exergames have attracted the interest of academics, practitioners, and designers, in domains as diverse as health, human-computer interaction, psychology, and information technology. This is primarily because exergames can make the exercise experience more enjoyable and entertaining, and in turn, can increase exercise levels. Despite the many benefits of exergames, they suffer from retention problems. Thus, the objective of this article was to review theories and game elements that have been empirically examined or employed in an attempt to make exergames more motivating so people engage in sustained physical activity (duration of physical activity) in a repeating pattern over time (frequency of physical activity). Methodology. A literature search and narrative review were conducted. Results. Five major theories and elements were prevalent in the exergaming literature: (1) self-determination theory, (2) gamification, (3) competition and cooperation, (4) situational interest, and (5) social interaction. These theories and elements are important for encouraging long-term play and show promise for designing exergames to promote sustained engagement and motivate physical activity. We discuss their strengths and weaknesses throughout the paper. Conclusions. The longterm effectiveness of exergame interventions is unclear mainly because of the limited amount of long-term studies. Better metrics are also needed to evaluate this effectiveness. We also identified particular attention to social factors and group dynamics, such as multiplayer exergames and more effective player matchmaking strategies for increasing social connectedness, as a key area of future research. 


\section{Motivational Strategies and Approaches for Single and 2 Multi-Player Exergames: A Social Perspective}

3 Gerry Chan ${ }^{1}$, Ali Arya ${ }^{1}$, Rita Orji², Zhao Zhao ${ }^{3}$

$4{ }^{1}$ Carleton School of Information Technology, Carleton University, Ottawa, Ontario, Canada

$5 \quad$ 2Faculty of Computer Science, Dalhousie University, Halifax, Nova Scotia, Canada

$6{ }^{3}$ Department of Systems and Computer Engineering, Carleton University, Ottawa, Ontario, 7 Canada

8

9 Corresponding Author:

10 Gerry Chan ${ }^{1}$

111125 Colonel By Drive, Ottawa, Ontario, K1S 5B6, Canada

12 Email address: gerrychan@,cmail.carleton.ca

13 


\section{Abstract}

15 Background. Exergames have attracted the interest of academics, practitioners, and designers, in 16 domains as diverse as health, human-computer interaction, psychology, and information

17 technology. This is primarily because exergames can make the exercise experience more 18 enjoyable and entertaining, and in turn, can increase exercise levels. Despite the many benefits 19 of exergames, they suffer from retention problems. Thus, the objective of this article is to review 20 theories and game elements that have been empirically examined or employed in an attempt to 21 make exergames more motivating so people engage in sustained physical activity (duration of 22 physical activity) in a repeating pattern over time (frequency of physical activity).

23 Methodology. A literature search and narrative review were conducted.

24 Results. Five major theories and elements were prevalent in the exergaming literature: (1) self25 determination theory, (2) gamification, (3) competition and cooperation, (4) situational interest, 26 and (5) social interaction. These theories and elements are important for encouraging long-term 27 play and show promise for designing exergames to promote sustained engagement and motivate 28 physical activity. We discuss their strengths and weaknesses throughout the paper.

29 Conclusions. The long-term effectiveness of exergame interventions is unclear mainly because 30 of the limited number of long-term studies completed to date. Better metrics are also needed to 31 evaluate this effectiveness. We also identified particular attention to social factors and group

32 dynamics, such as multi-player exergames and more effective player matchmaking strategies for 33 increasing social connectedness, as a key area of future research.

\section{Introduction}

35 A sedentary lifestyle is linked to many health concerns. Research suggests that sedentary 36 behavior - activities that involve extensive amounts of sitting such as television viewing and 37 desk-bound work, are associated with an increased risk of developing metabolic dysfunction, 38 cardiovascular disease, obesity, and lower levels of psychosocial health and well-being 39 (Tremblay, Colley, Saunders, Healy, \& Owen, 2010). In contrast, living an active lifestyle 40 through engaging in regular exercise and physical activity is associated with many health 41 benefits (Alpert, 2009). However, common complaints associated with participation in exercise 
42 include factors such as lack of social support, perceived feelings of exhaustion, and

43 inconvenience of environmental conditions (Myers \& Roth, 1997). As a result, research has

44 increased focused on how to harness the power of technology to support people to be physically

45 active. These efforts have led to the emergence of videogames that require players use a range of

46 active body motions and hence encouraging physical activity in a fun and engaging way. Such

47 games are commonly referred to as "exergames". Exergames ${ }^{1}$, which are a combination of

48 exercise and videogames (Yim \& Graham, 2007), can make doing exercise more enjoyable, and

49 offer a safe, entertaining, and engaging environment to motivate people to participate in physical

50 activity (Altamimi \& Skinner, 2012). In this paper, we use the term exergame as a gamified

51 experience that combines physical activity (traditional exercise which involves "planned,

52 structured, repetitive" movements (Caspersen, Powell, \& Christenson, 1985) or other types of

53 practice that makes the player physically active) using game elements.

54 Despite the numerous benefits of exergames, they suffer from retention problems (Graves,

55 Ridgers, Atkinson, \& Stratton, 2016; Rhodes et al., 2019; Sun, 2012). While some games entice

56 players to crave more play-time, other games dissuade players before they reach the next level or

57 the end-goal of a game. The problem of maintaining players motivation and keeping actively

58 engaged is commonly referred to as player retention or game sustainability, and has been an

59 important and long-running investigation in the gaming community (Debeauvais, Shapiro, Nardi,

60 Ducheneaut, \& Yee, 2010; Weber, Mateas, \& Jhala, 2011). In this paper, the terms "retention"

61 and "sustainability" are used interchangeably to describe a player's continued participation in an

62 activity (such as exercise activity, videogame play, or exergame play) over time. While players'

63 participation is the primary goal in this regard, keeping them motivated can be the strongest tool

64 the designers have, although participation is a function of many other parameters. Also, it is

65 possible that players may discontinue playing a game, but continue being active through playing

66 other exergames or participating in other physical activities/sports. Since the designer of any

67 particular game may not know about what happens after the player leaves, the participation in the

68 context of this paper refers to continued play in the same game. The duration of sustainability

\footnotetext{
${ }^{1}$ Exergames are also commonly referred to as active video games, active gaming, movement-controlled video games, or exertion games, in which interaction of the interface requires physical effort (Yim et al., 2007; Mueller et al., 2010).
} 
69 would continue until the player reaches the end of the game; but ideally, to keep living an active 70 lifestyle, the player would move onto a new game, repeat play of the same game, until they are

71 able to maintain their exercise routine without needing any motivation eventually, hence forming

72 habitual health behaviours (Aarts, Paulussen, \& Schaalma, 1997).

73 The purpose of this review is to study the strategies, theories, principles and practices that are

74 considered by the existing research when designing exergames to increase players' motivation as

75 a means of increasing participation and as such improving retention/sustainability. This includes

76 the approaches that researchers have employed in an attempt to create a more engaging and

77 enjoyable play experience. Although much research on exergames exist and is ongoing, there

78 remain open questions about how we can keep players motivated over the long-term. The

79 following three questions about exercise and videogames are explored in this paper:

80 - What social features can be integrated in exergames to motivate and sustain engagement?

82

- How can existing theories and motivational strategies (particularly from social psychology and personality) be used to optimize the exergame experience and encourage continued play in a sustained and repeated pattern over time?

85 The research presented in this paper was motivated by these open questions and our observation

86 of limited attention to some motivating factors such as social interaction in existing research.

87 The field of exergames has been reviewed recently by other researchers, for example: the social

88 effects of exergames on older adults (Theng et al., 2018); the effectiveness of gamification in 89 exergames (Matallaoui, Koivisto, Hamari, \& Zarnekow, 2017); and the psychological effects of

90 playing exergames (Lee, Kim, Park, \& Peng, 2017). However, there is a lack of investigation and

91 evaluation on social features used in exergames to increase motivation, particularly considering

92 the long-term effects. This review offers a new perspective on the motivational and social

93 aspects of exergame retention. It contributes a multidisciplinary understanding of how to design

94 exergames to motivate players and sustain engagement, through effective use of social features

95 in the design of exergames.

96 Our specific contributions can be grouped as follows: 
97

98

99

100

101

102

103

104

105

106

107

108

109

110

111 The remainder of this paper is structured as follows. First, we report on the process employed to

112 conduct the review and the results. Then, we provide an overview of popular motivational

113 approaches and strategies that have been studied in the videogame and exergame literature as

114 they relate to game play followed by an evaluation of the five major categories. Based on our

115 evaluation each category, we identify gaps in the current body of literature and offer a discussion

116 of directions for future research together with potential research questions.

\section{2. Literature Review}

\subsection{Research Approach}

119 To achieve the intended objective of this paper, we reviewed both theoretical and empirical 120 evidence concerning the motivational aspects of exergame play. We employed a snowball 121 method (Wohlin, 2014) where we started with some initial set and used their references, both

122 backward and forward iterations, until we no longer found significant new work.

123 For our literature search, we used Google Scholar as our first data source. The terms active video 124 games and exergames, together with the terms enjoyment $(n=4,150)$, engagement $(n=5,670)$, 125 and motivation $(n=7,540)$ were all included in the search process that used the full body of 
126 articles. We also searched other databases including PsycINFO, ACM Digital Library, Scopus

127 and Springer using the same search terms. This ensures good coverage of empirical studies on

128 exergames across various fields including Human-Computer Interaction (HCI), technology,

129 psychology, computer games, and other related disciplines. These disciplines were selected for

130 the search because they are the home to most research on games, gamification, and

131 understanding the player experience. Research projects were included when researchers (a)

132 examined the effects of videogame play - predominantly exergames, (b) explored and measured

133 some outcome variable related to motivation (e.g.: enjoyment and engagement) and (c) studied

134 the psychology of the player and playing behaviours, particularly related to continued play.

135 Papers with key terms such as "active video games", "exergames", "motion-based games" and

136 "motivation" were all included in the analysis. Included in the search were also reviews of

137 research specifically conducted on exergames (Altamimi \& Skinner, 2012; Kari, 2015; Kooiman

138 \& Sheehan, 2015; Lee, Kim, Park, \& Peng, 2017; Lyons, 2014; Matallaoui, Koivisto, Hamari, \&

139 Zarnekow, 2017; Mellecker, Lyons, \& Baranowski, 2013; Peng, Crouse \& Lin, 2013). Reference

140 sections of review papers were chosen for inclusion in this review when there was some kind of

141 theoretical component(s) or outcome measure(s) related to the psychology of motivation and

142 social interactions.

143 To ensure that we cover a wide range of concepts and theories related to videogame play, in

144 addition to the initial keyword search, we also examined other literature pertaining to all types of

145 videogames (e.g.: mobile, single-player, multiplayer online role-playing, and many others).

146 Then, because of our particular interest in the social aspects of play, we focused mainly on

147 multiplayer videogames and social motivations for playing exergames. Not all general topics in

148 videogames are significant or applicable in the special case of exergames. Thus, we further

149 explored literature that we believed were applicable to exergames and relevant for understanding

150 the effects of continued play which included motivational theories, as well as other related

151 theories that have been researched in videogames. During the database search process we

152 included articles that discussed the design and evaluation of motivational and social approaches.

153 We excluded important topics such as aesthetics that are relevant to all games (and other

154 applications) but are not specifically significant for exergames or are not relevant for the current

155 context of this review. Papers describing the design and development of exergames without an

156 evaluation component and without psychological theory were also excluded. Data extractions in 
157 accordance with the research questions posed in this review were conducted concurrently with

158 deciding on the papers to include or exclude. We also searched in specific journals (e.g.: Games

159 for Health Journal) and conferences (e.g.: ACM CHIPlay) that are likely to include more papers

160 on the topic.

161 After scanning through the titles, abstracts and keywords of the articles we gathered from our

162 initial search, 90 papers were selected as starting set (seed) of snowball based on relevance, date

163 and citation count. We made sure the seed papers were as diverse as possible with regards to

164 authors, publishers, and topic. We performed backward and forward snowballing, reviewing

165 papers in the reference lists of our articles and those that have cited our articles. The results of

166 snowball yielded more than 500 unique titles of which 132 papers and books were deemed

167 relevant (meeting our inclusion criteria) following an examination of the titles, abstracts and full

168 body text. Out of these 132 references, some of them were theoretical papers $(n=18)$ while

169 some described actual user studies $(n=83)$, and many were review papers $(n=31)$. Figure 1

170 summarizes the study identification process.

171 Among the exergame studies that were deemed to fit the scope of this review, we identified 30

172 articles (17 journal articles, 12 conference papers, 1 book chapter) as typical examples of work

173 on the subject and included in a more detailed discussion (listed in Table 1) while all papers were

174 reviewed. The collection of 30 typical papers was published from 2009 to May 2019 and

175 demonstrates the most common trends in exergame motivational strategies. For example, many

176 researchers have studied the motivational and social aspects of competitive and cooperative

177 exergame play employing similar methods, outcome measures and take on the same theoretical

178 foundations (e.g.: Hsieh \& Peng, 2012; Song, Kim, Tenzek, \& Lee, 2013b; Staiano, Abraham, \&

179 Calvert, 2012).

180 While in the survey particularly focused on the 30 selected articles, we included other examples

181 in our references and mentioned them in the appropriate section. We also included theoretical

182 and survey papers that reviewed related topics such as increasing the level of enjoyment

183 experienced in exergames (e.g.: Lyons, 2014; Mellecker, Lyons, \& Baranowski, 2013).

184 Enjoyment was included because it has been associated with continued motivation and social 185 aspects in exergames. 
187 Research shows that motivation is the most important force for determining a player's desire for

188 continued play (Stankevicius, Jady, Drachen, \& Schoenau-Fog, 2015) and in an exergame

189 context, consideration of self-efficacy is particularly important for maintaining motivation over

190 time through setting achievable goals (Macvean \& Robertson, 2013). Motivation can be defined

191 as the driving force behind all the actions of an individual (Rabideau, 2005) and most researchers

192 agree that most motivation theories attempt to explain three interrelated aspects of human

193 behaviour: 1) the choice of a particular action 2) the persistence of a particular action, and 3) the

194 effort expended on a particular action (Dörnyei, 2000). One theory that is commonly associated

195 with motivation is the "flow" theory (Csikszentmihalyi, 1977) which is characterized as a mental

196 state marked by complete absorption and high concentration of an activity. Chen (2007) argues

197 that a well-designed videogame will motivate repetitive play and "transports" its players to their

198 personal "Flow Zones" - where a person's abilities are matched by a challenge, delivering

199 genuine feelings of pleasure and happiness. Moreover, games should adapt to the player's skills

200 in order to keep them in the flow zone. If the challenge exceeds the person's abilities, "anxiety"

201 will be experienced, whereas too little challenge leads to "boredom" (Fig. 2). In the context of

202 exergames, Huang et al. (2018) found that competitive individuals have an enhanced need for

203 feelings of achievement and are focused on overcoming challenges, and thus, can easily

204 experience flow. The researchers also found that perceived challenge and exercise enjoyment

205 were both positively related to the experience of flow.

206 Furthermore, Crutzen, Riet and Short (2015) aimed to clarify the concept of enjoyment among

207 other related constructs such as fun and engagement in the context of games for promoting health

208 behaviours. The researchers reviewed empirical studies and found that concepts such as flow,

209 engagement, and fun are associated with enjoyment. Engagement which refers to [the level of

210 motivation that a player displays in gameplay reflecting a psychological process (Caroux,

211 Isbister, Le Bigot, \& Vibert, 2015)] is related to immersion which refers to [a state of high

212 motivation to play the game, while retaining some awareness of one's surroundings (Baños et al.,

213 2004)] and presence which refers to [the experience of being personally and physically inside a

214 virtual environment (Wirth et al., 2007)]. Both engagement and enjoyment are important for

215 keeping high levels of motivation and thus, are key factors for designing games that aim to 
216 promote health behaviours. Crutzen et al. (2016) concluded their review suggesting that other

217 researchers use enjoyment, and enjoyment only, to refer to the action or state of deriving

218 gratification from a game, and identified three important factors for increasing the level of

219 enjoyment while designing health games: 1) competence, 2) narrative transportation, and 3)

220 relevance (Table 2).

221 Many researchers have explored the value of videogames for encouraging participation in

222 physical activity (Altamimi \& Skinner, 2012; Whitehead, Johnston, Nixon, \& Welch, 2010) and

223 have identified principles for designing successful exergames (Mandryk, Gerling, \& Stanley,

224 2014; Yim \& Graham, 2007). There is also a substantial amount of research regarding the

225 motivational aspects of videogame play (e.g.: Kooiman \& Sheehan, 2017; Przybylski, Rigby, \&

226 Ryan, 2010; Ryan, Rigby, \& Przybylski, 2006; Yee, 2007). Macvean and Robertson (2013)

227 suggest that in order to sustain exergame play longitudinally, designers need to consider how to

228 positively influence participants' motivation. Lyons et al. (2014) and Lyons (2014) further

229 suggest that maintaining high levels of enjoyment, which is a component of motivation, is

230 essential to promoting continued game-play and exercise adherence.

231 However, not all games are well-designed and thus, are unable to keep players motivated. Dias

232 and Martinho (2011) suggest that all videogames eventually "lose their charm and the interest of

233 the player" and by then, players should have already experienced all the key features, yet many

234 game stop being fun before they have the chance to do that. This occurs because of two reasons:

235 1) players do not relate to the challenge they are assigned, and 2) players do not appreciate the

236 rewards the game is giving them in return for their efforts (Chen, 2007). Research shows that

237 factors such as lack of time to play, loss of interest because players no longer find the current

238 game fun, the novelty of a different game (Tyack, Wyeth, \& Johnson, 2016), unsatisfactory

239 player-to-player matchmaking recommendations for facilitating social connectedness (Horton,

240 Johnson, \& Mitchell, 2016) and player toxicity (unsportsmanlike behaviors that are displayed by

241 a player that are undesired by other players) (Riegelsberger, Counts, Farnham, \& Philips, 2007),

242 can all result in players quitting a game. As for exergames, there is research suggesting that

243 some exergames may not be able to maintain long-term interest in exercise (Sun, 2013a) and

244 reasons for not engaging with exergames over a long-term include factors such as games not

245 being useful enough, lack of time, and preference for other forms of exercise (Kari, Makkonen, 
246 Moilanen, \& Frank, 2012). By understanding the factors that attract players and the factors that

247 do not, designers can tailor the design to keep motivation levels high, attract new players, while

248 sustaining already existing ones.

249 The subsequent sections offer an analysis of some of the most common theories and elements

250 that have been applied to study the motivational effects of exergame play. These are self-

251 determination theory, gamification, competition and cooperation, situational interest, and social

252 interactions. The boundaries between these theories and elements are relatively fluid in that

253 some of them are often studied collectively and share similar properties with each other. For

254 example, the psychological need of relatedness from Ryan and Deci's (2000) Self-Determination

255 Theory (SDT) is often studied by means of social interaction, as well as cooperation.

256 Gamification is also often conceptualized with respect to intrinsic and extrinsic motivation which

257 was emerged from the SDT.

\section{$258 \quad 2.3$ Self-Determination Theory}

259 Self-Determination Theory (SDT) is a macro-theory derived from empirical work on human 260 motivation and personality in social contexts (Ryan \& Deci, 2000). There are three conditions 261 supporting the SDT: 1) autonomy, 2) competence, and 3) relatedness. Autonomy refers to the 262 perception of being in control of one's own activities and decisions, competence refers to the 263 perception of increasing mastery of skills, and relatedness refers to the perceived development 264 and maintenance of close personal relationships. All three conditions are necessary to foster the 265 most "volitional and high quality" forms of motivation for engaging in activities involving 266 enhanced performance, persistence, and creativity (Ryan \& Deci, 2000). SDT further assumes 267 that people are "active organisms" and can be viewed in relation to intrinsic [doing an activity 268 simply for the enjoyment of the activity itself, rather than for external rewards or pressures (Ryan $269 \&$ Deci, 2000)], and extrinsic [doing an activity in order to attain some separable outcome or 270 value (Ryan and Deci, 2000)] motivation represented along a continuum (Fig. 3). In quantitative 271 studies measuring intrinsic motivation, the concept of game enjoyment is commonly associated 272 with an individual's experience of fun and their level of interest (Mekler, Bopp, Tuch, \& Opwis, 273 2014). 
274 From a psychological perspective, Deci and Ryan (2000) claim that autonomy, competence, and 275 relatedness can also be conceptualized as essential human needs. In the context of videogames, 276 Przybylski et al. (2010) proposed a motivational model of videogame engagement based on SDT 277 to provide experiences that satisfy universal human needs. According to the model, video games 278 are motivational because they satisfy the need for autonomy, competence, and relatedness. SDT 279 is one of the most prominent theories used to inform the design and evaluation in the exergame 280 literature (Kooiman \& Sheehan, 2015; Lindgaard, 2018). Researchers such as Boulos and Yang 281 (2013) have proposed a framework (Fig. 4) based on SDT for conducting future research 282 particularly on children's motives for participating in games. The researchers recommend that 283 research should aim to understand the types of activities that children already find compelling 284 and motivating, which may include enjoyment or physical appearance or weight loss. The 285 researchers further posit that if players feel competent during play, they are more likely to 286 continue playing because continued feeling of competence will likely lead to intrinsically287 motivated behaviours resulting in outcomes such as higher levels of physical activity, enjoyment 288 and adherence.

289 Other researchers such as Lin et al. (2012) have conducted some empirical work to examine the 290 usefulness of the SDT in the context of exergames and found evidence that exergame features 291 appear to influence basic needs for satisfaction of players. Results showed that several game 292 design strategies and choices available in the game, such as the ability to customize and increase 293 the strength of the avatar, supported the need for autonomy. The ability to dynamically adjust 294 the level of difficulty based on a player's performance and achievement indicators satisfied the 295 need for competence. Additionally, the researchers reported that autonomy-supportive and 296 competence-supportive game features led to higher levels of game enjoyment, higher levels of 297 motivation for future play, and greater self-efficacy for exercise using the game, and greater 298 game rating. However, no effects of the need satisfaction-supportive game features on players' 299 self-reported effort exerted in gameplay were found. The researchers concluded that "theory300 prescribed" game features contribute to the experience of enjoyment, motivation and engagement 301 through feelings of need satisfaction and recommended that future research intending to harness 302 the power of videogames needs to include game features that support need satisfaction to 303 increase the level of enjoyment, motivation and engagement outcomes. 
304 In a related research, Osorio, Moffat and Sykes (2012) have also studied the SDT in exergames, 305 particularly as it relates to a social context. Surveys were conducted to investigate the 306 motivations that encourage participation in exergames and found that the need for both 307 autonomy and relatedness were highly satisfied within a social context, yet the need for 308 competence was lower compared to the other two needs. The researchers speculated that this 309 was because exergaming was perceived as a social activity and that participation in exergames 310 might be motivated by the enjoyment of social interactions rather than competition. More 311 recently, Limperos and Schmierbach (2016) examined the relationship between exergame play 312 experiences, enjoyment, and intentions for continued play, and found that player performance 313 directly and indirectly predicts feelings of psychological responses (autonomy, competence, and 314 presence), enjoyment of the experience, and the likelihood for future play. In particular, they 315 reported that players who achieved better performance experienced greater levels autonomy, 316 presence, and enjoyment. They concluded that performance in exergames is related to the 317 player's psychological experiences that motivate enjoyment and the intention for continued play.

318 Hsia, Katzmarzyk, Newton, Staiano and Beyl (2016) conducted a 12-week study to examine the 319 potential "transfer effects" [become more physically active outside game play (Hsia et al., 2016)]

320 of exergaming on external behaviours such as physical activity levels, screen time and

321 physiological constructs. Overweight or obese adolescents were selected to participate in an 322 exergaming intervention, 60 minute sessions of group-based dance sessions 3 times per week, or 323 a no-treatment care control group. Participants were given the freedom to choose the intensity 324 and game play among a variety of dance-based games. At the end of 12 weeks, participants 325 answered questions regarding media use, self-efficacy towards physical activity and level of 326 intrinsic motivation. The group which participated in the intervention reported high levels of 327 intrinsic motivation to play exergames and high levels of self-efficacy towards physical activity.

328 Results also showed that adolescents highly enjoyed the exergaming experience and intend to 329 continue play in the future. This is one of the first studies in this literature review so far that 330 attempts to transform passive screen time to active screen time. Although evidence for transfer 331 effects on physical activity was not significant, it still provided some support for the idea that 332 videogames can be used to as an effective tool for motivating physical activity. 
333 To summarize, there is an abundance of literature supporting the SDT, particularly at the

334 individual level and researchers continue to examine SDT with respect to the likelihood of

335 exergames informed by SDT to facilitate player retention and prolonged play.

3362.4 Gamification

337 Gamification refers to the application of game principles in non-game contexts (Deterding,

338 Dixon, Khaled, \& Nacke, 2011) and is inherent in all exergames. An exergame without

339 gamification would be only exercise. While gamification by itself is not necessarily a social

340 strategy, some game features can consist of social mechanics, such as leaderboard where players

341 are able to see and compare their own performance with other players. How to effectively use

342 gamification features (particularly social features) as a motivator in exergames to sustain long-

343 term play has been the research objective of many studies (e.g.:Brauner, Calero Valdez,

344 Schroeder, \& Ziefle, 2013; Hamari \& Koivisto, 2015). Gamification has been applied to a variety

345 of health-related applications to promote a positive influence on health and wellness behaviors in

346 recent years (Pereira, Duarte, Rebelo, \& Noriega, 2014) and can work by providing a source of

347 motivation for one to engage in physical activity. Deterding (2012) argue that in order for

348 gamification to be successful, proper "game design" elements (Schell, 2008) must be included,

349 not simply game components. Despite the growing interest in persuasive games and gamified

350 systems for motivating health-related behaviours (Orji \& Moffatt, 2018; Orji, Nacke, \& Di

351 Marco, 2017), the majority of persuasive games employ a non-tailored approach to their design

352 (Busch et al., 2015). Although some researchers are attempting to design better measure

353 instruments to more accurately evaluate user preferences and motivations to use a gamified

354 system (Tondello et al., 2016), very little research has been done to design better metrics to

355 evaluate player preferences and motivations for personalizing the experience specifically in the

356 context of exergames.

357 Matallaoui et al. (2017) reviewed existing empirical research on the deployed motivational

358 affordances and the effectiveness of including gamification features in exergames. The

359 researchers conducted the review based on a framework proposed by Hamari et al. (2014)

360 consisting of 3 major elements: 1) the motivational affordances (i.e.: game elements employed in

361 a game system such as progress badges or leaderboards), 2) the psychological outcomes that are

362 induced by the motivational affordances (i.e.: the psychological processes such as competition, 
363 achievement and self-expression), and 3) the resulting and pursued behavioural and quasi-

364 medical outcomes (attitudes) such as increased physical activity and measured health benefits.

365 Results revealed positive psychological outcomes such as enjoying the exercise experience, as

366 well as behavioural ones such as decreasing sedentary behaviours and motivating engagement in

367 exercise. However, the researchers also identified some shortcomings in the literature such as

368 the use of a small sample size and non-validated scales, the majority of studies were based on

369 user evaluation rather than control groups and relatively short timeframes, as well as the lack of

370 linkage between theory and practice. The researchers concluded that among the literature

371 reviewed, there were only a few studies that considered proper game design for promoting

372 physical activity. Thus, the researchers recommended that more theory-based studies are needed

373 to examine the effectiveness of different gamification elements and mechanics in exergames.

374 Macvean and Robertson (2013) conducted a seven-week long case study to examine how users'

375 physical activity, motivation and behaviour changes over-time. The concept of self-efficacy

376 [how well one can execute courses of action required to deal with prospective situations

377 (Bandura, 1982)] was applied within the context of a school based exergame intervention,

378 including how players set goals and manage different levels of difficulty. Results showed that

379 participants were motivated by different factors. While some participants were highly motivated

380 by earning points other players strived to improve performance and setting goals. In particular,

381 differences were found within individual preferences with respect to how points were treated -

382 some were interested in earning points by competing with peers, some enjoyed keeping points

383 hidden from others while some preferred to broadcast their achievements.

384 Zhao et al. (2017) conducted a 70-day study on the effects of wearable-based exergames. In

385 particular, the researchers were interested in whether or not the gradual release of game features

386 can improve engagement over time. Participants were divided into three different groups: Group

3871 received a game with basic features, Group 2 received full features (i.e.: customization and

388 multiplayer modes), and Group 3 gradually received new features that were unlocked every 10

389 days. The behavioural patterns of each group were tracked and at the end of the study,

390 participants completed a post-study questionnaire to evaluate their experience during the study.

391 Results showed that the level of engagement in exercise and game-play are highly related, and

392 that the gradual addition of new features increases the amount of application usage and overall 
393 physical activity. Results also showed that a gamified exercise experience was more preferable 394 compared to a regular exercise experience.

395 Furthermore, researchers such as Geelan et al. (2016) attempted to increase both the duration and

396 the intensity of exercise activity by designing a system that combines traditional exercise

397 equipment such as exercise bicycles with videogames to provide additional interactive feedback

398 and motivation through exergame components. Results indicate that the addition of augmented

399 reality and videogames to existing exercise routines along with gamified elements, can increase

400 the level of energy expenditure and the amount of time spent exercising compared to non-

401 gamified exercise equipment. However, whether or not this approach is able to hold the

402 attention of players over the long-term is open to question and thus, the researchers identify this

403 as an opportunity for future research to examine the sustainability of exercise activities. In a

404 different study, Kappen et al. (2017) explored the effects of gamified motivational affordances

405 (the properties of an object that determine whether and how it can support one's motivational

406 needs (Zang, 2008)) for facilitating physical activity preferences and found that various age

407 groups are motivated by different kinds of motivational affordances (Table 3) which consists of

408 both intrinsic and extrinsic elements, as well as feedback elements (Table 4).

409 In general, the effectiveness and ways to gamify exercise routines continues to be a subject of

410 interest for many game designers and researchers. Research results suggest that a number of

411 elements (both intrinsic and extrinsic rewards) are important for inclusion in the design of

412 exercise interventions and that more studies are needed to examine different gamification

413 elements that can be used to encourage long-term play.

\subsection{Competition and Cooperation}

415 Competition and cooperation (same team playing together to achieve a shared/common

416 objective) are features offered in traditional videogames and are important elements in game

417 enjoyment and influences player's choice of games (Vorderer, Hartmann, \& Klimmt, 2003).

418 Previous research has shown that competition and cooperation both have an influence on

419 exercise performance, motivation and enjoyment (Peng \& Crouse, 2013; Staiano, Abraham, \&

420 Calvert, 2013). Marker and Staiano (2015) conducted a review of existing literature on the

421 effects of social exergaming, specifically how competitive and cooperative components of social 
422 play influence physical activity and motivation. They found that cooperative exergaming

423 promotes self-efficacy, intrinsic motivation, pro-social behaviours, and continued gameplay,

424 whereas competitive exergaming may promote short-term physiological arousal, and acute bouts

425 of aggression. Furthermore, Song et al. (2013a), investigated the role of competitive and

426 cooperative play on intrinsic motivation in the context of exergames and found that players who

427 were highly competitive enjoyed playing competitive games, whereas players who were not

428 competitive exercised just as hard as competitive individuals, but did not enjoy their experience.

429 The researchers concluded that further research is needed to study the effects of competition on

430 motivation in exergames and recommended that game design could tailor game-play to

431 individual differences for increased exercise motivation.

432 Some researchers have adopted the idea of personality-based tailoring (Mattheiss, Hochleitner,

433 Busch, Orji, \& Tscheligi, 2017; Tondello, Wehbe, Orji, Ribeiro, \& Nacke, 2017) and have

434 conducted studies to explore the effects of adapting games based on competitive/cooperative

435 preferences in game-play of an individual. For example, Shaw et al. (2016) designed a virtual

436 trainer system which adapts to a player's level of competitiveness/cooperativeness and found that

437 the game was particularly enjoyable and motivating when the system aligned with the

438 personality of the player. Additionally, Chan et al. (2017) examined the effects of competitive

439 and cooperative attitudes in paired play situations and found that competitive individuals prefer

440 playing alone, whereas cooperative individuals enjoy playing together. To increase the level of

441 enjoyment between player pairs, the researchers recommended that if player pairs favour the use

442 of cooperative strategies for success, then offer cooperative game scenarios. In contrast, if player

443 pairs favour the use of competitive strategies for success, then offer individual or competitive

444 scenarios.

445 In a different study, Hagen, Chorianopoulos, Wang, Jaccheri and Weie (2016) designed "Pedal

446 Tanks", which is an online competitive multiplayer stationary bicycle exergame based on

447 common team-based shooter games, as well as features from Multiplayer Online Battle Arena

448 (MOBA) games. The researchers evaluated the game and reported that the level of enjoyment,

449 physical exertion, and interest were all higher compared to moderate pace walking. However,

450 the study was only conducted with 8 participants in 3 game sessions which is not enough to draw

451 conclusions that the game is able to motivate long-term play. In a more recent study, the same 
452 research group reported that Pedal Tanks is highly enjoyable and is capable of encouraging high-

453 intensity interval training (Moholdt, Weie, Chorianopoulos, Wang, \& Hagen, 2017). They

454 concluded that this form of training can be a viable option for motivating those who have no

455 interest in exercise. Consistent with the findings of Hagen et al. (2016) and Moholdt et al.

456 (2017), researchers such as Monedero, Lyons and O'Gorman (2015) also observed that

457 competitive cycling videogames elicited higher levels of energy expenditure and were rated more

458 enjoyable than conventional stationary cycling exercises.

459 In a related research, Staiano et al. (2013) conducted a 7-months study to examine the effects of 460 competitive and cooperative play on self-efficacy. Results of the study revealed that cooperative 461 exergame players lost significantly more weight than the control group who gained weight over 462 time and competitive exergame players did not lose weight. The researchers theorized that

463 cooperation may foster a team bond experience more so than competition which could have 464 motivated persistent play. Results also showed that adolescents who lost weight were more 465 likely to have high initial levels of peer support which may promote group cohesion and provide 466 social reinforcements that aid in sustaining play in the cooperative condition. The effects of 467 competitive/cooperative behaviours in exergames remain a popular research topic for many 468 videogame researchers and designers.

469 In summary, researchers have found that not all players enjoy competitive playing scenarios and 470 rather than employing a "one-size-fits-all” approach (Orji, Mandryk, Vassileva, \& Gerling,

471 2013) designers and researchers are attempting to personalize the exergaming experience, as well

472 as conducting long-term studies to examine the effects of competitive and cooperative play.

\subsection{Situational Interest}

474 Situational interest refers to an interactive psychological state that occurs at the moment there is 475 a match between a person and an activity (Chen, Darst, \& Pangrazi, 1999) and has been 476 identified as a powerful motivator particularly in the educational context (Hidi, 2001). Deci

477 (1992) has suggested that teachers, who promote student autonomy and choice in their 478 classrooms, increase the level of intrinsic motivation and situational interest. Within the context 479 of physical education, Chen et al. (1999) developed a multidimensional model of situational 
480 interest which consists of five sources: 1) novelty, 2) challenge, 3) attention demand, 4)

481 exploration intention, and 5) instant enjoyment.

482 These sources have been studied in the context of exergames. For example, researchers such as

483 Pasco et al. (2017) designed a mobile application-based exergame that can be paired wirelessly

484 using Bluetooth technology to an exercise bike and evaluated its effectiveness for motivating

485 moderate-to-vigorous levels of physical activity and generating greater levels of situational

486 interest. Results showed that the mean scores for participants' physical activity levels,

487 situational interest sources, and total interest differed significantly between the experimental

488 group and the control group. The researchers concluded that their design is effective for

489 promoting light levels of physical activity, situational interest, and other important psychological

490 determinants of physical activity participation compared to conventional biking exercise. In a

491 different study, Sun (2013b) examined the effectiveness of exergames for motivating physical

492 activity during physical education class over a two semester period. Seventy grade 5 students

493 rotated between eight different gaming stations to engage in a different full body movement

494 games. Measurements were obtained to assess physical intensity and situational interest.

495 Results revealed that the amount of physical activity increased overtime, yet interest declined.

496 Additionally, boys reported higher levels of game enjoyment compared to girls, and both boys

497 and girls reported lasting feelings of challenge, exploration, and instant enjoyment. It was

498 concluded that although there is evidence that exergames may have strong motivational power at

499 the initial stages of game play, yet whether or not it is able to sustain motivation in the long-term

500 is questionable.

501 Overall, situational interest seems to be an effective strategy for designing exergames and

502 increasing exercise intensity, but the long-term effects are unknown.

$503 \quad 2.7$ Social Interaction

504 From the Human-Computer Interaction (HCI) perspective, Dourish (Dourish, 2002) argues that

505 physical and embodied features of interactive systems are related to the features of social

506 settings. However, Salen and Zimmerman (2013) suggest that design alone cannot warrant

507 social play - designers can offer features that facilitate social play, but it is the players who

508 create it. Bekker et al. (2010) explain that social interaction can be provoked by a game which is 
509 played by multiple players and the type of relationship between the players can influence the 510 type of social interactions that occur. Yee (2007) developed an empirical model of player

511 motivations in online games which identified "social interaction" as one overarching component

512 which consists of three subcomponents:

513 1. Socializing: having an interest in helping and chatting with other players;

514 2. Relationships: the desire to form long-term meaningful relationships with others, and;

515 3. Teamwork: deriving satisfaction from being part of a group effort.

516 These sub-components provide a foundation for conducting quantitative research in online

517 games to better understand usage patterns, in-game behaviours, and demographic variables such

518 as age and gender, with respect to player motivations.

519 In a videogame context, research shows that social interaction is important for experiencing 520 enjoyment $^{2}$ (Anwar et al., 2017; Sweetser \& Wyeth, 2005) and exertion games can facilitate 521 social play in computer mediated environments (Mueller, Gibbs, \& Vetere, 2009; Mueller,

522 Gibbs, \& Vetere, 2010). Research also shows that social presence (Ekman et al., 2012), social 523 connections (Przybylski et al., 2010), social benefits (Granic, Lobel, \& Engels, 2014), and the

524 experience of social relatedness (Kooiman \& Sheehan, 2015) are common motivations for

525 videogame play. Furthermore, research in videogames suggest that social presence is an

526 important determinant of player enjoyment (Gajadhar, De Kort, \& Ijsselsteijn, 2008) and

527 mediating factors drawn from behavioural health theory such as communication and social

528 support can be impactful methods for designing videogames to encourage exercise behaviours

529 (Lieberman et al., 2011). In the context of exergames, cooperative play increases social

530 interactions (Park, Yoo, Choe, Park, \& Song, 2012) and engaging in social interactions, during

531 exergame play is an important experience leading to increased immersion between players (Lee

532 et al., 2017). There is also some research suggesting that pre-existing social relationships (e.g.:

533 friends) are not enough to sustain long-term motivation for physical activity and suggest that

\footnotetext{
${ }^{2}$ Other components of flow include concentration, challenge, skill, control, goals, feedback and immersion. Sweetser and Wyeth (2005) suggest that social interaction is not an element of flow, but is a strong element of enjoyment in games. The researchers further explain that social interaction is not a property of the task as are the other elements of flow, but the task is a means to allow social interaction.
} 
534 increasing game complexity and variations can help to encourage long-term exergame play (Caro 535 et al., 2018). Recently, Kaos et al. (2019) conducted a six-week study and found that social play

536 have superior adherence compared to individual play because based on SDT (Edward L. Deci,

537 1992), players who engaged in social play allowed them to experience a sense of belongingness

538 - a universal human need to form and maintain relationship with others (Baumeister \& Leary, 539 1995), was satisfied.

540 Mueller et al. (2009) studied the potential of exertion games for facilitating social play in

541 networked environments. The researchers conducted a qualitative analysis of one particular case

542 study on 39 participants in 13 distinct teams of 3 players and identified six salient themes on how

543 exertion games can facilitate social play (Table 5). Games designers who are interested in

544 designing games which offer social interaction can use these six themes as a guide on how to

545 include exertion aspects, as well as exertion applications that currently do not support social 546 play.

547 In summary, designers and researchers are interested in developing playful experiences that 548 support social interactions. Social support and communication are key mediators for

549 encouraging behaviour change and continued play. However, pre-existing social relationships

550 between players are insufficient for sustained long-term play. Games that offer a variety of

551 challenges and gradual release of game features can encourage longer-term play.

\section{3. Gap Analysis}

\subsection{Summary of Findings}

554 To summarize, using the snowball method, we conducted a review on some of the most common 555 theories and elements that researchers have studied in the exergaming literature. Our aim was to 556 search for motivators that particularly enhance long-term play. We learned that the SDT,

557 gamification, competition and cooperation, social interaction, and situational interest are the 558 main categories that represent the most active approaches in existing research in this area (Table

559 1). We also learned that the social aspect of an activity and social experiences are important 560 motivators for continued exergame play. An interesting trend that we noticed was that many 561 game designers and researchers are gradually moving away from designing for and researching 562 exercise games that are confined to indoors and require gaming consoles. Increasingly, they are 
563 exploring the effectiveness of exergames that are app-based for outdoor play and researching 564 exergame experiences where exercises occur outside of play sessions. Another trend that we 565 gathered was rather than designing based on a "one-size fits-all" approach, many designers and

566 researchers are beginning to explore the effects of a more tailored approach to better satisfy

567 individual and group differences, as well as personalize the game experience.

\section{$568 \quad 3.2$ Discussion}

569 Current literature suggests that exergames can be an effective tool for increasing exercise 570 motivation and are generally rated more enjoyable compared to traditional forms of exercises.

571 While some research suggest that commercially available off-the-shelf videogames are capable

572 of providing light-to-moderate levels of physical activity (Peng et al., 2013), other research

573 shows that due to inconsistent results and the overall poor methodological quality of some

574 studies, whether or not exergames are suitable to meet physical activity guidelines for different

575 population groups are inconclusive (Christoph, Michael, \& Arno, 2016). There is also some

576 research suggesting that the physical demand of some exergames are not intense enough to

577 contribute towards the recommended daily amount of exercise for children because these games

578 do not require the same level of energy expenditure as the actual sport (Graves, Stratton, Ridgers,

$579 \&$ Cable, 2007). Exergames can be designed to adjust intensity. For example, to encourage

580 adequate energy expenditure, Whitehead et al. (2010) propose that exergames must consist of

581 two core features: 1) rewards for encouraging long-term motivation and, 2) better features or

582 game-play that will involve full body movements. To prevent overexertion, Schneider and

583 Graham (2017) investigated the use of "nudges" (Thaler \& Sustein, 2017) and found that nudges

584 motivated players to slow down, and fit naturally into the games.

585 To promote longer-term play, designers and researchers are investigating various strategies and

586 mechanics in addition to the game itself such as gamifying the exercise experience (Matallaoui et

587 al., 2017; Mueller, Peer, Agamanolis, \& Sheridan, 2011) and personalizing the experience

588 (Göbel, Hardy, \& Wendel, 2010), cultivating group cohesion using smart watch interactions

589 (Esakia, Harden, McCrickard, \& Horning, 2017), augmenting traditional exercise equipment

590 with gamified elements (Geelan et al., 2016), adapting content presentation (Dias \& Martinho,

591 2011), increasing situational interest (Pasco et al., 2017; Sun, 2013b), tailoring virtual coaching

592 to individual personalities (Shaw et al., 2016) and many others. Research shows that experience 
593 of fun and social affiliation are good predictors of long-term intention to playing exergames

594 (Adam \& Senner, 2016). Player achievement predicts feelings of autonomy, competence,

595 presence, enjoyment and continued motivation to play exergames (Limperos \& Schmierbach,

596 2016). Although informative, there could be other elements that could encourage longer-term

597 play that remain unexplored. More research is needed to understand what individual (e.g.:

598 personality dimensions and motivational orientations), social (e.g.: competition vs. cooperation)

599 and cultural (e.g.: individualistic vs. collectivistic preferences) factors which might or might not

600 encourage continued exergame play.

601 In addition to the elements and theories that we presented in this literature review, we recognize

602 that there are many other factors, theories and elements that can make a game attractive and fun

603 to play. For example, other elements that make games compelling include opportunities to

604 master a task or learn and practice a new skill (Koster, 2013), construct, explore, and interact

605 with the game-world environment (Moore \& Sward, 2006), as well as experience a fictional

606 world (Juul, 2005). However, we believe that the elements and theories we reviewed in this

607 survey paper are particularly useful for understanding retention of exergames.

608 3.3 Active Research Questions and Directions for Future Research

609 Many questions remain unanswered regarding how we can explore and apply these motivational

610 theories and elements that encourage long-term play. Below are some unexplored research

611 questions provoked by the discussion above as researchers continue to investigate theories and

612 elements for encouraging exergame adherence over the long-term. We offer three general areas

613 for further investigation: 1) enrichment of the social experience and tailoring to the individual, as

614 well as, group personality, 2) development of metrics specialized for evaluating the exergaming

615 experience, and 3) conduct longitudinal studies to better understand the effects of competition,

616 cooperation and situational interest on exergame adherence over a longer period of time.

\section{3.3.1 Social Experiences}

618 More research is needed to uncover optimal player tailoring and pairing mechanisms for

619 facilitating group play. Research shows that in a competitive exergame context, the level of

620 intrinsic motivation increases for players who are highly competitive yet decreases for players

621 who are less competitive (Song et al., 2013a). It is important to tailor the game experience based 
622 on individual preferences to attract all player types. Chan et al. (2017) found that matching game

623 scenario and individual attitudes to a player's competiveness and cooperativeness increases the

624 level of enjoyment. However, the effects of attitude pairings in larger groups and the long-term

625 effects of competitive and cooperative play are still unknown. Social exergames are popular

626 because they offer competitive and cooperative experiences that are similar to group exercise

627 (Marker \& Staiano, 2015) and supportive peer relationships encourage exercise adherence

628 (Murcia, Román, Galindo, Alonso, \& González-Cutre, 2008). However, current exergame

629 research seems to focus mainly on designing for single player (e.g.: (Geelan et al., 2016; Shaw et

630 al., 2016)) rather than multiple players. Although some researchers (e.g.: (Choi, Oh, Edge, Kim,

631 \& Lee, 2016; Esakia et al., 2017; Zhao et al., 2017)) are investigating the potential of wearable

632 devices for encouraging participation in physical activity and positive group cohesion, there is

633 not enough research examining the effects of social interaction and social connectedness in

634 larger groups. Additionally, although some researchers are beginning to study the effects of

635 group play and have found that group exergaming can provide enjoyable physical activity

636 experiences (Staiano, Beyl, Hsia, Katzmarzyk, \& Newton, 2018), there is very little research on

637 how to form groups that motivates continued play.

638 Potential Research Questions:

639 1. What social elements enhance group play?

640 2. What exergame features can be offered to enhance feelings of social affiliation for

$641 \quad$ increasing adherence to long-term play?

642 3. How can an exergame be designed to offer a more cohesive group experience?

643 4. How can the issue of small sample size in the majority of studies be addressed?

644 5. What design improvements can be made to personalize the exergame experience to $645 \quad$ increase the effectiveness for multiple players?

\section{$646 \quad 3.3 .2 \quad$ Personality-Based Solutions}

647 In social settings, people can sometimes get along well and build positive relationships but other 648 times they can remain distant. Research across a number of contexts of human social activity

649 has shown that the compatibility between people depends on the degree to which their

650 personalities are similar (Tenney, Turkheimer, \& Oltmanns, 2009). It is likely that situations,

651 where people get along well, could be because they share common interests and have similar 
652 personalities. Alternatively, situations, where people remain distant, could be due to lack of 653 common interests and personality clashes. Personality [a set of individual attributes that 654 consistently differentiate persons from each other in the ways they think, feel, and act (Ones, 655 Viswesvaran, \& Dilchert, 2005)] has been shown to play an important role in many areas of HCI 656 including user-interface design (Nov \& Arazy, 2013), gamification (Codish \& Ravid, 2014; Orji, 657 Tondello, \& Nacke, 2018), and video games (Braun, Stopfer, Müller, Beutel, \& Egloff, 2016; 658 DeGraft-Johnson, Wang, Sutherland, \& Norman, 2013). In exergames, Mattheiss et al. (2017) 659 examined the personality of Pokémon Go players on motivation to continue play and found that

660 players who play the game score low on conscientiousness, whereas players who stopped playing 661 the game after 3 months score higher on neuroticism. This is an important finding because as 662 researchers continue to explore the relationships between social exergame play and personality, 663 understanding which personality types are more or less likely to continue play can help designers 664 tailor the social experiences to satisfy individual players, but also groups of players.

665 The literature about personality-based tailoring and matching in exergames is still in its infancy.

666 The results of some studies (e.g.: Orji, Nacke, \& Di Marco, 2017; Shaw et al., 2016) suggest that 667 a tailored approach, particularly in the context of persuasive games and gamified systems, are 668 more effective at motivating health-related behaviours compared to a non-tailored approach.

669 However, the long-term effects of these approaches still remain unknown.

670 Potential Research Questions:

671 1. Do different personalities prefer different types of rewards?

672 2. Does personality composition of groups play a role in exergame retention?

673 3. What personality compositions are more likely to encourage continued play and which $674 \quad$ ones do not?

675

676 3.3.3 Metrics for Evaluating the Exergaming Experience

677 In a narrative review, Mellecker et al. (2013) proposed that validated personality tests should be 678 applied to exergame play for experiencing enjoyment. To date, most commonly used metrics for 679 evaluating player experiences such as the level of enjoyment is a subscale of the Intrinsic 680 Motivation Inventory (McAuley, Duncan, \& Tammen, 1989), which is a questionnaire based on 
681 the SDT or the 10-item Positive Affect/Negative Affect Scale (Watson David, Clark Lee Anna,

682 \& Tellegen Auke, 1988), social presence - the Social Presence Gaming Questionnaire (Kort,

683 IJsselsteijn, \& Poels, 2007), engagement - the User Engagement Scale (Wiebe, Lamb, Hardy, \&

684 Sharek, 2014). Yet, none of these instruments were specifically developed for evaluating player

685 experiences in an exergame context. New metrics not only need to be developed for evaluating

686 personality, but also other factors which could specifically influence the player's exergame

687 experience. Lee et al. (2017) indentified that one major limitation in exergaming research is that

688 most studies to date rely on measures developed for either normal exercise or sedentary digital

689 games. Thus, the researchers recommend that a unique evaluation for measuring the

690 psychological effects of exergames is needed because exergames are different from sedentary

691 video games and traditional kinds of exercise. Exergames consist of features such as the level of

692 exertion, which might not be present in other games such as sedentary videogames or online

693 games and are important aspects of creating an enjoyable experience (Lee et al., 2017). Another

694 limitation with respect to assessing player experiences in exergames is that majority of research

695 relies on survey reports and subjective data. More research should aim to gather objective

696 measures such as heart rate or galvanic skin response because they provide good validation for

697 subjective reports in a co-located, collaborative play environment (Mandryk \& Inkpen, 2005).

698 Potential Research Questions:

699

1. How can scales be improved to better measure outcome variables that target the

700 motivational effects of exergames?

701

702

2. What other measures can be collected to give a better picture of exergame interest, enjoyment and engagement?

703 3.3.4 Call for Longitudinal Studies

704 Finally, longer-term studies are also needed in the realm of exergames. Macvean and Robertson 705 (2013) conducted a 7-week study on user's physical activity, motivation and behavioral patterns 706 on using exergames, and suggested that longitudinal studies are necessary for evaluating

707 motivational effects, since it ensures that the intensity of a user's behavior is appropriate and 708 sustained. Likewise, Marker and Staiano (2015) highlighted that no studies have tracked 709 changes in physical activity with respect to social exergaming in competitive versus cooperative 710 contexts long-term. Long-term studies are important, particularly for exergames, because if 
711 aspects of the game (e.g.: technology, other players, content presentation) is inadequate for

712 sustained play, game designers can refine game elements to ensure optimal playing experience.

713 Potential Research Questions:

714 1. What are the long-term effects of competitive and cooperative in social exergaming?

7152 2. Is situational interest effective at motivating continued exercise interest in exergames $716 \quad$ over the long-term?

\section{4. Conclusions}

718 In closing, many researchers and game designers are exploring various technological solutions to 719 reduce sedentary behaviors and leverage interest for sustained physical activity. One possible 720 solution is exergames because they can make exercise seem more enjoyable and engage players.

721 Research shows that exergames are effective at motivating people to participate in exercise.

722 However, simply adding game elements to an activity or gamifying exercise routines may not 723 necessarily increase the level of motivation and achieve the desired outcomes. Research also 724 suggested that exergames may not be able to motivate exercise interest over a long-term and 725 some games are inadequate for encouraging intense physical activity that are necessary to reap 726 the full health benefits.

727 In this review, we identified that SDT is one of the most commonly used theories to inform the 728 design and evaluation in the exergame literature. In particular, satisfying the need to belong is an 729 important component for designing multiplayer exergames because it increases the likelihood of 730 game adherence. Principles of gamification and motivational affordances have been applied in 731 attempt to make participation in traditional exercise more interesting. The results of these 732 studies show that gamifying the exercise experience can lead to increased enjoyment, exercise 733 time, and physical exertion. Furthermore, we learned that recent technologies such as virtual 734 reality combined with gamification features can easily be added to traditional exercise equipment 735 such as a stationary bike can make the exercise experience more interesting. Competition and 736 cooperation are also popular components for motivating exergame play. We came across many 737 studies showing that some players are motivated by competition while others are motivated by 738 cooperation and when designing exergames, tailoring scenarios based on one's

739 competitive/cooperative preferences can increase the level of game enjoyment. Offering 
740 opportunities for social interaction between players can also enhance exergame play, and

741 including elements of situational interest can increase the level of exertion, as well as make the

742 exercise activity more enjoyable. However, there were studies that evaluated the long-term

743 effectiveness of situational interest on exergame adherence and found that prolonged exposure to

744 exergaming activities could lead to decrease perception of situational interest and in turn, could

745 lower motivation to participate in exergames-based physical activities in the future.

746 Finally, as online exergames become more popular, there will be a wide range of possible player-

747 pairings. This creates an opportunity for people to be brought together dynamically to play

748 exergames and engage in social interactions in a way that might increase or decrease the level of

749 motivation among multiple players. Thus, it is important to understand how these pairings can

750 motivate interest and encourage long-term participation beyond the novelty of a new game or

751 technology keeping players highly engaged and motivated so that they keep on returning to the

752 game, and ultimately continue an exercise plan, as well as an active lifestyle.

\section{Acknowledgements}

754 This paper is dedicated to the memory of our friend and colleague, Dr. Anthony Whitehead, who

755 contributed to the planning and defining the early stages of this work.

\section{References}

757

758

759

760

761

762

763

764

765

766

767

768

769

770

771

772

773

774

Aarts, H., Paulussen, T., \& Schaalma, H. (1997). Physical exercise habit: On the conceptualization and formation of habitual health behaviours. Health Education Research, 12(3), 363-374. https://doi.org/10.1093/her/12.3.363

Adam, C., \& Senner, V. (2016). Which Motives are Predictors for Long-term Use of Exergames? Procedia Engineering, 147, 806-811. https://doi.org/10.1016/j.proeng.2016.06.310

Alpert, P. T. (2009). Exercise Works. Home Health Care Management \& Practice, 21(5), 371374. https://doi.org/10.1177/1084822309334032

Altamimi, R., \& Skinner, G. (2012). A Survey of Active Video Game Literature: from theory to technilogical application. International Journal of Computer and Information Technology, 01(01), 20-35.

Anwar, A., Johnson, D., Sweetser, P., Meng, Y., Ozdowska, A., \& Wyeth, P. (2017). GameFlow in Different Game Genres and Platforms. Computers in Entertainment, 15(3), 1-24. https://doi.org/10.1145/3034780

Baños, R. M., Botella, C., Alcañiz, M., Liaño, V., Guerrero, B., \& Rey, B. (2004). Immersion and Emotion: Their Impact on the Sense of Presence. CyberPsychology \& Behavior, 7(6), 734-741. https://doi.org/10.1089/cpb.2004.7.734

Baumeister, R. F., \& Leary, M. R. (1995). The Need to Belong: Desire for Interpersonal Attachments as a Fundamental Human Motivation. Psychological Bulletin, 117(3), 497- 
775

776

777

778

779

780

781

782

783

784

785

786

787

788

789

790

791

792

793

794

795

796

797

798

799

800

801

802

803

804

805

806

807

808

809

810

811

812

813

814

815

816

817

818

819

820

529. https://doi.org/10.1037/0033-2909.117.3.497

Bekker, T., Sturm, J., \& Eggen, B. (2010). Designing playful interactions for social interaction and physical play. Personal and Ubiquitous Computing, 14(5), 385-396. https://doi.org/10.1007/s00779-009-0264-1

Boulos, M. N. K., \& Yang, S. P. (2013). Exergames for health and fitness: The roles of GPS and geosocial apps. International Journal of Health Geographics, 12. https://doi.org/10.1186/1476-072X-12-18

Braun, B., Stopfer, J. M., Müller, K. W., Beutel, M. E., \& Egloff, B. (2016). Personality and video gaming: Comparing regular gamers, non-gamers, and gaming addicts and differentiating between game genres. Computers in Human Behavior, 55, 406-412. https://doi.org/10.1016/j.chb.2015.09.041

Brauner, P., Calero Valdez, A., Schroeder, U., \& Ziefle, M. (2013). Increase Physical Fitness and Create Health Awareness through Exergames and Gamification, 349-362. https://doi.org/10.1007/978-3-642-39062-3_22

Busch, M., Mattheiss, E., Orji, R., Marczewski, A., Hochleitner, W., Lankes, M., ... Tscheligi, M. (2015). Personalization in Serious and Persuasive Games and Gamified Interactions. Proceedings of the 2015 Annual Symposium on Computer-Human Interaction in Play - CHI PLAY '15, 811-816. https://doi.org/10.1145/2793107.2810260

Caro, K., Feng, Y., Day, T., Freed, E., Fox, B., \& Zhu, J. (2018). Understanding the Effect of Existing Positive Relationships on a Social Motion-based Game for Health, 77-87. https://doi.org/10.1145/3240925.3240942

Caroux, L., Isbister, K., Le Bigot, L., \& Vibert, N. (2015). Player-video game interaction: A systematic review of current concepts. Computers in Human Behavior, 48, 366-381. https://doi.org/10.1016/j.chb.2015.01.066

Caspersen, C. J., Powell, K. E., \& Christenson, G. M. (1985). Physical activity, exercise, and physical fitness: definitions and distinctions for health-related research. Public Health Reports (Washington, D.C. : 1974), 100(2), 126-131. https://doi.org/10.2307/20056429

Chan, G., Whitehead, A., \& Parush, A. (2017). Dynamic player pairing: Quantifying the effects of competitive versus cooperative attitudes. Game Dynamics: Best Practices in Procedural and Dynamic Game Content Generation, 71-93. https://doi.org/10.1007/978-3-319-5308885

Chen, A., Darst, P. W., \& Pangrazi, R. P. (1999). What constitutes situational interest? Validating a construct in physical education. Measurement in Physical Education and Exercise Science, 3(3), 157-180. https://doi.org/10.1207/s15327841mpee0303_3

Chen, J. (2007). Flow in games (and everything else). Communications of the ACM, 50(4), 31. https://doi.org/10.1145/1232743.1232769

Choi, W., Oh, J., Edge, D., Kim, J., \& Lee, U. (2016). SwimTrain: Exploring Exergame Design for Group Fitness Swimming. Proceedings of the 2016 CHI Conference on Human Factors in Computing Systems - CHI '16, 1692-1704. https://doi.org/10.1145/2858036.2858579

Christoph, H., Michael, S., \& Arno, S.-T. (2016). Effects of Exergaming on Physical Activity in Overweight Individuals. Sports Medicine, 46(6), 845-860. https://doi.org/10.1007/s40279015-0455-z

Codish, D., \& Ravid, G. (2014). Personality Based Gamification: How Differente Personalities Perceive Gamification. Ecis, 11.

Crutzen, R., van 't Riet, J., \& Short, C. E. (2016). Enjoyment: A Conceptual Exploration and Overview of Experimental Evidence in the Context of Games for Health. Games for Health

Peer) Comput. Sci. reviewing PDF | (CS-2019:05:37954:1:1:NEW 7 Sep 2019) 
821

822

823

824

825

826

827

828

829

830

831

832

833

834

835

836

837

838

839

840

841

842

843

844

845

846

847

848

849

850

851

852

853

854

855

856

857

858

859

860

861

862

863

864

865

866

Journal, 5(1), 15-20. https://doi.org/10.1089/g4h.2015.0059

Csikszentmihalyi, M. (1977). Beyond Boredom and Anxiety: Experiencing Flow in Work and Play. The Jossey-Bass Behavioral Science Series, 231. https://doi.org/10.2307/2065805

DA, L., Chamberlin, B., Jr, M. E., BA, F., BM, S., \& DK, V. (2011). The power of play: Innovations in Getting Active Summit 2011: a science panel proceedings report from the American Heart Association. Circulation, 123(21), 2507-2516.

https://doi.org/10.1161/CIR.0b013e318219661d

Debeauvais, T., Shapiro, D. J., Nardi, B., Ducheneaut, N., \& Yee, N. (2010). If You Build It They Might Stay: Retention Mechanisms in World of Warcraft. 6th International Conference on the Foundations of Digital Games (FDG 2011), 1-8. https://doi.org/10.1145/2159365.2159390

DeGraft-Johnson, C., Wang, Y.-C., Sutherland, M. B., \& Norman, K. L. (2013). Relating Five Factor Personality Traits to Video Game Preference. Human-Computer Interaction Technical Report, (HCIL-2013-08), 1-16.

Deterding, S. (2012). Gamification: Designing for Motivation. Interactions, 19(4), 14-17. Retrieved from http://dl.acm.org/ft_gateway.cfm?id=2212877\&type=pdf\&dwn=1\#page=16\%5Cnhttp://dl.a cm.org/ft_gateway.cfm?id=2212877\#page $=16$

Deterding, S., Dixon, D., Khaled, R., \& Nacke, L. (2011). From Game Design Elements to Gamefulness: Defining "Gamification." MindTrek'11 Proceedings of the 15th International Academic MindTrek Converence: Envisioning Future Media Environments, 9-15. https://doi.org/10.1145/1979742.1979575

Dias, R., \& Martinho, C. (2011). Adapting Content Presentation and Control to Player Personality in Videogames. Proceedings of the 8th International Conference on Advances in Computer Entertainment Technology, 18:1-18:8.

https://doi.org/10.1145/2071423.2071446

Dörnyei, Z. (2000). Motivation in action: Towards a process-oriented conceptualisation of student motivation. British Journal of Educational Psychology, 70(4), 519-538. https://doi.org/10.1348/000709900158281

Dourish, P. (2002). Where the action is: the foundations of embodied interaction. Philosophical Psychology (Vol. 15).

Edward L. Deci. (1992). The Relation of interest to the Motivation of Behaviour: A SelfDetermination Theory Perspective. The Role of Interest in Learning and Development, 43. Retrieved from https://www.msu.edu/ dwong/CEP991/CEP991Resources/DeciInterest\&Motiv.pdf

Ekman, I., Chanel, G., Järvelä, S., Kivikangas, J. M., Salminen, M., \& Ravaja, N. (2012). Social Interaction in Games: Measuring Physiological Linkage and Social Presence. Simulation and Gaming, 43(3), 321-338. https://doi.org/10.1177/1046878111422121

Esakia, A., Harden, S. M., McCrickard, D. S., \& Horning, M. (2017). FitAware: Channeling Group Dynamics Strategies with Smartwatches in a Physical Activity Intervention Andrey. Proceedings of the 2017 CHI Conference Extended Abstracts on Human Factors in Computing Systems - CHI EA '17, 2551-2559. https://doi.org/10.1145/3027063.3053249

Gajadhar, B. J., De Kort, Y. A. W., \& Ijsselsteijn, W. A. (2008). Shared fun is doubled fun: Player enjoyment as a function of social setting. Lecture Notes in Computer Science (Including Subseries Lecture Notes in Artificial Intelligence and Lecture Notes in Bioinformatics), 5294 LNCS, 106-117. https://doi.org/10.1007/978-3-540-88322-7-11

Peer] Comput. Sci. reviewing PDF | (CS-2019:05:37954:1:1:NEW 7 Sep 2019) 
867 Geelan, B., Zulkifly, A., Smith, A., Cauchi-saunders, A., Salas, K. De, Lewis, I., ... Lewis, I. 
913

914

915

916

917

918

919

920

921

922

923

924

925

926

927

928

929

930

931

932

933

934

935

936

937

938

939

940

941

942

943

944

945

946

947

948

949

950

951

952

953

954

955

956

957

958 https://doi.org/10.1145/3116595.3116604

Kari, T. (2015). Can exergaming promote physical fitness and physical activity? A systematic review of systematic reviews. Gamification: Concepts, Methodologies, Tools, and Applications, 4-4, 2022-2038. https://doi.org/10.4018/978-1-4666-8200-9.ch103

Kari, Tuomas, Makkonen, M., Moilanen, P., \& Frank, L. (2012). The Habits of Playing and the ReasonsforNot Playing Exergames: Gender Differences in Finland. 25th EConference EDependability, 11(1), 30-42. Retrieved from http://urn.fi/URN:NBN:fi:jyu-201312132794

Kooiman, B. J., \& Sheehan, D. P. (2015). The efficacy of exergames for social relatedness in online physical education. Cogent Education, 2(1). https://doi.org/10.1080/2331186X.2015.1045808

Kooiman, B. J., \& Sheehan, D. P. (2017). Motivation to Move with Exergaming in Online Physical Education. International Journal of Physical Education, Fitness and Sports, 3(2), 01-24. https://doi.org/10.26524/1421

Kooiman, B., \& Sheehan, D. D. (2015). Exergaming Theories: A Literature Review. International Journal of Game-Based Learning, 5(4), 1-14. Retrieved from https://search.proquest.com/docview/1871577650?accountid=13963\%0Ahttp://resolver.ebs cohost.com/openurl?ctx_ver=Z39.88-2004\&ctx_enc=info:ofi/enc:UTF8\&rfr_id=info:sid/ProQ\%3Aeric\&rft_val_fmt=info:ofi/fmt:kev:mtx:journal\&rft.genre=artic le\&rft.jtitle=Interna

Kort, Y. de, IJsselsteijn, W. A., \& Poels, K. (2007). Digital Games as Social Presence Technology: Development of the Social Presence in Gaming Questionnaire (SPGQ). Presence, 195-203. Retrieved from http://sag.sagepub.com/cgi/doi/10.1177/1046878111422121

Koster, R. (2013). A Theory of Fun for Game Design. Journal of Chemical Information and Modeling (Vol. 53). https://doi.org/10.1017/CBO9781107415324.004

Lee, S., Kim, W., Park, T., \& Peng, W. (2017). The Psychological Effects of Playing Exergames: A Systematic Review. Cyberpsychology, Behavior, and Social Networking, 20(9), 513-532. https://doi.org/10.1089/cyber.2017.0183

Limperos, A. M., \& Schmierbach, M. (2016). Understanding the Relationship Between Exergame Play Experiences, Enjoyment, and Intentions for Continued Play. Games for Health Journal, 5(2), 100-107. https://doi.org/10.1089/g4h.2015.0042

Lin, J.-H., Winn, B., Peng, W., \& Pfeiffer, K. a. (2012). Need Satisfaction Supportive Game Features as Motivational Determinants: An Experimental Study of a Self-Determination Theory Guided Exergame. Media Psychology, 15(2), 175-196. https://doi.org/10.1080/15213269.2012.673850

Lindgaard, G. (2018). Games and exergames in rehabilitation. Interactions, 25(4), 24-25. https://doi.org/10.1145/3229364

Lyons J., E., Tate F., D., Ward S., D., Ribisl M., K., Bowling M., J., \& Kalyanaraman, S. (2014). Engagement, Enjoyment, and Energy Expenditure During Active Video Game Play. Health Psychology, 33(2), 174-181. https://doi.org/10.1037/a0031947

Lyons, E. J. (2014). Cultivating Engagement and Enjoyment in Exergames Using Feedback, Challenge, and Rewards. Games for Health Journal, 4(1), 12-18. https://doi.org/10.1089/g4h.2014.0072

Macvean, A., \& Robertson, J. (2013). Understanding exergame users' physical activity, motivation and behavior over time, 1251. https://doi.org/10.1145/2470654.2466163

Mandryk, R. L., Gerling, K. M., \& Stanley, K. G. (2014). Designing Games to Discourage 
959

960

961

962

963

964

965

966

967

968

969

970

971

972

973

974

975

976

977

978

979

980

981

982

983

984

985

986

987

988

989

990

991

992

993

994

995

996

997

998

999

1000

1001

1002

1003

1004

Sedentary Behaviour. Playful User Interfaces, 253-274. https://doi.org/10.1007/978-9814560-96-2

Mandryk, R. L., \& Inkpen, K. M. (2005). Physiological indicators for the evaluation of colocated collaborative play, 102. https://doi.org/10.1145/1031607.1031625

Marker, A. M., \& Staiano, A. E. (2015). Better Together: Outcomes of Cooperation Versus Competition in Social Exergaming. Games for Health Journal, 4(1), 25-30. https://doi.org/10.1089/g4h.2014.0066

Matallaoui, A., Koivisto, J., Hamari, J., \& Zarnekow, R. (2017). How Effective Is "Exergamification"? A Systematic Review on the Effectiveness of Gamification Features in Exergames. Proceedings of the 50th Hawaii International Conference on System Sciences (2017). https://doi.org/10.24251/hicss.2017.402

Mattheiss, E., Hochleitner, C., Busch, M., Orji, R., \& Tscheligi, M. (2017). Deconstructing Pokémon Go - An Empirical Study on Player Personality Characteristics BT - Persuasive Technology: Development and Implementation of Personalized Technologies to Change Attitudes and Behaviors. In P. W. de Vries, H. Oinas-Kukkonen, L. Siemons, N. Beerlagede Jong, \& L. van Gemert-Pijnen (Eds.) (pp. 83-94). Cham: Springer International Publishing.

McAuley, E., Duncan, T., \& Tammen, V. (1989). Psychometric Properties of Intrinsic Inventory in a Competitve Sport Setting: A Confirmatory Factor Analysis. Research Quarterly: For Exercise and Sport, 60(1), 48-58.

Mekler, E. D., Bopp, J. A., Tuch, A. N., \& Opwis, K. (2014). A systematic review of quantitative studies on the enjoyment of digital entertainment games. Proceedings of the 32nd Annual ACM Conference on Human Factors in Computing Systems - CHI '14, 927-936. https://doi.org/10.1145/2556288.2557078

Mellecker, R., Lyons, E. J., \& Baranowski, T. (2013). Disentangling Fun and Enjoyment in Exergames Using an Expanded Design, Play, Experience Framework: A Narrative Review. Games for Health Journal, 2(3), 142-149. https://doi.org/10.1089/g4h.2013.0022

Moholdt, T., Weie, S., Chorianopoulos, K., Wang, A. I., \& Hagen, K. (2017). Exergaming can be an innovative way of enjoyable high-intensity interval training. BMJ Open Sport and Exercise Medicine, 3(1). https://doi.org/10.1136/bmjsem-2017-000258

Monedero, J., Lyons, E. J., \& O'Gorman, D. J. (2015). Interactive video game cycling leads to higher energy expenditure and is more enjoyable than conventional exercise in adults. PLoS ONE, 10(3). https://doi.org/10.1371/journal.pone.0118470

Moore, M., \& Sward, J. (2006). Introduction to The Game Industry (Game Design and Development Series). Retrieved from http://dl.acm.org/citation.cfm?id=1200557

Moreno Murcia, J. A., López De San Román, M., Martínez Galindo, C., Alonso, N., \& González-Cutre, D. (2008). Peers' influence on exercise enjoyment: A self-determination theory approach. Journal of Sports Science and Medicine, 7(1), 23-31.

Mueller, F. "Floyd," Gibbs, M. R., \& Vetere, F. (2009). Design influence on social play in distributed exertion games, 1539. https://doi.org/10.1145/1518701.1518938

Mueller, F. 'Floyd,' Peer, F., Agamanolis, S., \& Sheridan, J. (2011). Gamification and exertion. CHI 2011 Workshop on Gamification: Using Game Design Elements in Non-Game Contexts, 1-4. https://doi.org/978-1-4503-0268-5/11/05.

Mueller, F., Gibbs, M. R., \& Vetere, F. (2010). Towards understanding how to design for social play in exertion games. Personal and Ubiquitous Computing, 14(5), 417-424. https://doi.org/10.1007/s00779-009-0268-x

Peer] Comput. Sci. reviewing PDF | (CS-2019:05:37954:1:1:NEW 7 Sep 2019) 
1005

1006

1007

1008

1009

1010

1011

1012

1013

1014

1015

1016

1017

1018

1019

1020

1021

1022

1023

1024

1025

1026

1027

1028

1029

1030

1031

1032

1033

1034

1035

1036

1037

1038

1039

1040

1041

1042

1043

1044

1045

1046

1047

1048

1049

1050

Myers, R. S., \& Roth, D. L. (1997). Perceived Benefits of and Barriers to Exercise and Stage of Exercise Adoption in Young Adults. Health Psychology, 16(3), 277-283. https://doi.org/10.1037/0278-6133.16.3.277

Nakamura, J., \& Csikszentmihalyi, M. (2014). The concept of flow. In M. Csikszentmihalyi (Ed.), Flow and the Foundations of Positive Psychology: The Collected Works of Mihaly Csikszentmihalyi (pp. 239-263). Dordrecht: Springer Netherlands. https://doi.org/10.1007/978-94-017-9088-8_16

Nov, O., \& Arazy, O. (2013). Personality-targeted design: theory, experimental procedure, and preliminary results. Proceedings of the 2013 Conference on Computer ..., 977-984. https://doi.org/10.1145/2441776.2441887

Ones, D. S., Viswesvaran, C., \& Dilchert, S. (2005). Personality at work: Raising awareness and correcting misconceptions. Human Performance, 18(4), 389-404. https://doi.org/10.1207/s15327043hup1804_5

Orji, R., Mandryk, R. L., Vassileva, J., \& Gerling, K. M. (2013). Tailoring persuasive health games to gamer type. Proceedings of the SIGCHI Conference on Human Factors in Computing Systems - CHI '13, 2467. https://doi.org/10.1145/2470654.2481341

Orji, R., \& Moffatt, K. (2018). Persuasive technology for health and wellness: State-of-the-art and emerging trends. Health Informatics Journal, 24(1), 66-91. https://doi.org/10.1177/1460458216650979

Orji, R., Nacke, L. E., \& Di Marco, C. (2017). Towards Personality-driven Persuasive Health Games and Gamified Systems. Proceedings of the 2017 CHI Conference on Human Factors in Computing Systems - CHI '17, 1015-1027. https://doi.org/10.1145/3025453.3025577

Orji, R., Tondello, G. F., \& Nacke, L. E. (2018). Personalizing persuasive strategies in gameful systems to gamification user types. Conference on Human Factors in Computing Systems Proceedings, 2018-April. https://doi.org/10.1145/3173574.3174009

Osorio, G., Moffat, D. C., \& Sykes, J. (2012). Exergaming, Exercise, and Gaming: Sharing Motivations. Games for Health Journal, 1(3), 205-210. https://doi.org/10.1089/g4h.2011.0025

Park, T., Yoo, C., Choe, S. P., Park, B., \& Song, J. (2012). Transforming solitary exercises into social exergames, 863. https://doi.org/10.1145/2145204.2145332

Pasco, D., Roure, C., Kermarrec, G., Pope, Z., \& Gao, Z. (2017). The effects of a bike active video game on players' physical activity and motivation. Journal of Sport and Health Science, 6(1), 25-32. https://doi.org/10.1016/j.jshs.2016.11.007

Peng, W., \& Crouse, J. (2013). Playing in Parallel: The Effects of Multiplayer Modes in Active Video Game on Motivation and Physical Exertion. Cyberpsychology, Behavior, and Social Networking, 16(6), 423-427. https://doi.org/10.1089/cyber.2012.0384

Peng, W., Crouse, J. C., \& Lin, J. H. (2013). Using Active Video Games for Physical Activity Promotion: A Systematic Review of the Current State of Research. Health Education and Behavior, 40(2), 171-192. https://doi.org/10.1177/1090198112444956

Pereira, P., Duarte, E., Rebelo, F., \& Noriega, P. (2014). A review of gamification for healthrelated contexts. Lecture Notes in Computer Science (Including Subseries Lecture Notes in Artificial Intelligence and Lecture Notes in Bioinformatics), 8518 LNCS(PART 2), 742753. https://doi.org/10.1007/978-3-319-07626-3_70

Przybylski, A. K., Rigby, C. S., \& Ryan, R. M. (2010). A Motivational Model of Video Game Engagement. Review of General Psychology, 14(2), 154-166. https://doi.org/10.1037/a0019440 
1051 1052

1053

1054

1055

1056

1057

1058

1059

1060

1061

1062

1063

1064

1065

1066

1067

1068

1069

1070

1071

1072

1073

1074

1075

1076

1077

1078

1079

1080

1081

1082

1083

1084

1085

1086

1087

1088

1089

1090

1091

1092

1093

1094

1095

1096

Rhodes, R. E., Beauchamp, M. R., Blanchard, C. M., Bredin, S. S. D., Warburton, D. E. R., \& Maddison, R. (2019). Predictors of stationary cycling exergame use among inactive children in the family home. Psychology of Sport and Exercise, 41, 181-190. https://doi.org/10.1016/j.psychsport.2018.03.009

Richard, M. R., \& Edward, L. D. (2000). Self-Determination Theory and the Facilitation of Intrinsic Motivation, Social Development, and Well-Being. American Psychologist, 55(1), $68-78$.

Richard M. Ryan, C. Scott Rigby, \& Andrew Przybylski. (2006). The motivational pull of video games: A self-determination theory approach. Motivation and Emotion. https://doi.org/https://doi.org/10.1007/s11031-006-9051-8

Riegelsberger, J., Counts, S., Farnham, S. D., \& Philips, B. C. (2007). Personality matters: Incorporating detailed user attributes and preferences into the matchmaking process. Proceedings of the Annual Hawaii International Conference on System Sciences. https://doi.org/10.1109/HICSS.2007.434

Salen, K., Zimmerman, E., \& Contents, T. (2013). Rules of Play Game Design Fundamentals. International immunology (Vol. 25). https://doi.org/10.1093/intimm/dxs150

Schell, J. (2008). The art of game design: A book of lenses. The Art of Game Design: A Book of Lenses, 1-489. https://doi.org/10.1201/9780080919171

Schneider, A. L. J., \& Graham, T. C. N. (2017). Nudging and shoving: Using in-game cues to guide player exertion in exergames. Entertainment Computing, 19, 83-100. https://doi.org/10.1016/j.entcom.2017.01.002

Scoot T.Rabideau. (2005). Effects of Achievement Motivation on Behavior. Rochester Institute of Technology, 1. Retrieved from http://www.personalityresearch.org/papers/rabideau.html

Shaw, Lindsay A., Buckley, J., Corballis, P. M., Lutteroth, C., \& Wuensche, B. C. (2016). Competition and cooperation with virtual players in an exergame. PeerJ Computer Science, 2, e92. https://doi.org/10.7717/peerj-cs.92

Shaw, Lindsay Alexander, Tourrel, R., Wunsche, B. C., Lutteroth, C., Marks, S., \& Buckley, J. (2016). Design of a virtual trainer for exergaming. Proceedings of the Australasian Computer Science Week Multiconference on - ACSW'16, 1-9. https://doi.org/10.1145/2843043.2843384

Song, H., Kim, J., Tenzek, K. E., \& Lee, K. M. (2013a). The effects of competition and competitiveness upon intrinsic motivation in exergames. Computers in Human Behavior, 29(4), 1702-1708. https://doi.org/10.1016/j.chb.2013.01.042

Song, H., Kim, J., Tenzek, K. E., \& Lee, K. M. (2013b). The effects of competition and competitiveness upon intrinsic motivation in exergames. Computers in Human Behavior, 29(4), 1702-1708. https://doi.org/10.1016/j.chb.2013.01.042

Staiano, A. E., Abraham, A. A., \& Calvert, S. L. (2012). Motivating Effects of Cooperative Exergame Play. Journal of Diabetes Science and Technology, 6(4), 812-819. Retrieved from http://onlinelibrary.wiley.com/o/cochrane/clcentral/articles/810/CN00853810/frame.html

Staiano, A. E., Abraham, A. A., \& Calvert, S. L. (2013). Adolescent exergame play for weight loss and psychosocial improvement: a controlled physical activity intervention. Obesity (Silver Spring, Md.), 21(3), 598-601. https://doi.org/10.1002/oby.20282

Staiano, A. E., Beyl, R. A., Hsia, D. S., Katzmarzyk, P. T., \& Newton, R. L. (2018). A 12-week randomized controlled pilot study of dance exergaming in a group: Influence on psychosocial factors in adolescent girls. Cyberpsychology, 12 (2 Special Issue).

Peer] Comput. Sci. reviewing PDF | (CS-2019:05:37954:1:1:NEW 7 Sep 2019) 
1097

1098

1099

1100

1101

1102

1103

1104

1105

1106

1107

1108

1109

1110

1111

1112

1113

1114

1115

1116

1117

1118

1119

1120

1121

1122

1123

1124

1125

1126

1127

1128

1129

1130

1131

1132

1133

1134

1135

1136

1137

1138

1139

1140

1141

1142

https://doi.org/10.5817/CP2018-2-3

Stankevicius, D., Jady, H. A., Drachen, A., \& Schoenau-fog, H. (2015). A Factor-Based Exploration of Player 's Continuation Desire in Free-to-Play Mobile Games. Player Modeling: Papers from the AIIDE 2015 Workshop, 36-42.

Sun, H. (2012). Exergaming Impact on Physical Activity and Interest in Elementary School Children. Research Quarterly for Exercise and Sport, 83(2), 212-220. https://doi.org/10.5641/027013612800745248

Sun, H. (2013a). Impact of exergames on physical activity and motivation in elementary school students: A follow-up study. Journal of Sport and Health Science, 2(3), 138-145. https://doi.org/10.1016/j.jshs.2013.02.003

Sun, H. (2013b). Impact of exergames on physical activity and motivation in elementary school students: A follow-up study. Journal of Sport and Health Science, 2(3), 138-145. https://doi.org/10.1016/j.jshs.2013.02.003

Sweetser, P., \& Wyeth, P. (2005). GameFlow: A Model for Evaluating Player Enjoyment in Games. Computers in Entertainment, 3(3), 1-24. https://doi.org/10.1145/1077246.1077253

Tenney, E. R., Turkheimer, E., \& Oltmanns, T. F. (2009). Being liked is more than having a good personality: The role of matching. Journal of Research in Personality, 43(4), 579585. https://doi.org/10.1016/j.jrp.2009.03.004

Thaler, R., \& Sustein, C. (2017). Nudge: Improving decisions about health, wealth and happiness. Nudge: Improving Decisions About Health, Wealth and Happiness. https://doi.org/10.4324/9781912282555

Theng, Y.-L., Li, J., Chen, L., Erdt, M., Cao, Y., \& Lee, S.-Q. (2018). The Social Effects of Exergames on Older Adults: Systematic Review and Metric Analysis. Journal of Medical Internet Research, 20(6), e10486. https://doi.org/10.2196/10486

Tondello, G. F., Wehbe, R. R., Diamond, L., Busch, M., Marczewski, A., \& Nacke, L. E. (2016). The Gamification User Types Hexad Scale, 229-243. https://doi.org/10.1145/2967934.2968082

Tondello, G. F., Wehbe, R. R., Orji, R., Ribeiro, G., \& Nacke, L. E. (2017). A Framework and Taxonomy of Videogame Playing Preferences. Proceedings of the Annual Symposium on Computer-Human Interaction in Play - CHI PLAY'17, 329-340.

https://doi.org/10.1145/3116595.3116629

Tremblay, M. S., Colley, R. C., Saunders, T. J., Healy, G. N., \& Owen, N. (2010). Physiological and health implications of a sedentary lifestyle. Applied Physiology, Nutrition, and Metabolism, 35(6), 725-740. https://doi.org/10.1139/H10-079

Tyack, A., Wyeth, P., \& Johnson, D. (2016). The Appeal of MOBA Games: What Makes People Start, Stay, and Stop. Proceedings of the 2016 Annual Symposium on Computer-Human Interaction in Play - CHI PLAY '16, 313-325. https://doi.org/10.1145/2967934.2968098

Vorderer, P., Hartmann, T., \& Klimmt, C. (2003). Explaining the enjoyment of playing video games: The role of competition. Communication Research, (1), 1-9.

Watson David, Clark Lee Anna, \& Tellegen Auke. (1988). Development and Validation of Brief Measures of Positive and Negative Affect: The PANAS Scales. Journal of Personality and Social Psychology, 54(6), 1063-1070.

Weber, B. G., Mateas, M., \& Jhala, A. (2011). Using data mining to model player experience. Evaluating Player Experience. Retrieved from http://users.soe.ucsc.edu/ bweber/pubs/submission_3_epex_final.pdf

Whitehead, A., Johnston, H., Nixon, N., \& Welch, J. (2010). Exergame effectiveness.

Peer] Comput. Sci. reviewing PDF | (CS-2019:05:37954:1:1:NEW 7 Sep 2019) 
Proceedings of the 5th ACM SIGGRAPH Symposium on Video Games - Sandbox '10, 5562. https://doi.org/10.1145/1836135.1836144

Wiebe, E. N., Lamb, A., Hardy, M., \& Sharek, D. (2014). Measuring engagement in video gamebased environments: Investigation of the User Engagement Scale. Computers in Human Behavior, 32, 123-132. https://doi.org/10.1016/j.chb.2013.12.001

Wirth, W., Hartmann, T., Böcking, S., Vorderer, P., Klimmt, C., Schramm, H., ... Jäncke, P. (2007). A Process Model of the Formation of Spatial Presence Experiences. Media Psychology, 9(3), 493-525. https://doi.org/10.1080/15213260701283079

Wohlin, C. (2014). Guidelines for snowballing in systematic literature studies and a replication in software engineering, 1-10. https://doi.org/10.1145/2601248.2601268

Yee, N. (2007). Motivations for Play in Online Games. CyberPsychology \& Behavior, 9(6), 772775. https://doi.org/10.1089/cpb.2006.9.772

Yim, Jeffrey, Graham, T. C. N. (2007). Using games to increase exercise motivation. Future Play '07 Proceedings of the 2007 Conference on Future Play.

Zang, P. (2008). Technical opinion Motivational affordances: reasons for ICT design and use. Communications of the ACM, 5l(11), 145-147. https://doi.org/10.1145/1400214.1400244

Zhao, Z., Arya, A., Whitehead, A., Chan, G., \& Etemad, S. A. (2017). Keeping Users Engaged through Feature Updates: A Long-Term Study of Using Wearable-Based Exergames. Proceedings of the 2017 CHI Conference on Human Factors in Computing Systems - CHI '17, 1053-1064. https://doi.org/10.1145/3025453.3025982 


\section{Table $\mathbf{1}$ (on next page)}

Factors for increasing enjoyment in health games adapted from (Crutzen et al., 2016).

* Crutzen et al. (2016) hypothesized that competence is more important for influencing enjoyment, even more so than autonomy and relatedness. 


\begin{tabular}{|c|c|c|}
\hline Factor & Definition & Design Recommendations \\
\hline Competence* & $\begin{array}{l}\text { The perception of increasing } \\
\text { skills (Richard M. Ryan, C. } \\
\text { Scott Rigby, \& Andrew } \\
\text { Przybylski, 2006). }\end{array}$ & $\begin{array}{l}\text { Provide feedback, challenge and } \\
\text { rewards (Lyons, 2014). }\end{array}$ \\
\hline $\begin{array}{l}\text { Narrative } \\
\text { Transportation }\end{array}$ & $\begin{array}{l}\text { A process in which someone } \\
\text { is mentally "transported" } \\
\text { away from the physical world } \\
\text { into the imaginary world } \\
\text { presented in the form of a } \\
\text { story (Green \& Brock, 2000). }\end{array}$ & $\begin{array}{l}\text { Characters provide the driving } \\
\text { force or a narrative (Lu, } \\
\text { Baranowski, Thompson, \& } \\
\text { Buday, 2012) and the ethnic } \\
\text { similarity between game } \\
\text { characters and players enhances } \\
\text { immersion (Lu, Thompson, } \\
\text { Baranowski, Buday, \& } \\
\text { Baranowski, 2012). }\end{array}$ \\
\hline Relevance & $\begin{array}{l}\text { "Closely connected or } \\
\text { appropriate to the matter at } \\
\text { hand" (as cited in Crutzen et } \\
\text { al., 2016). Both "game world" } \\
\text { and "real world" relevance is } \\
\text { important for facilitating } \\
\text { enjoyment. }\end{array}$ & $\begin{array}{l}\text { Self-identification with game } \\
\text { characters. Games are most } \\
\text { intrinsically motivating when } \\
\text { players' experience of } \\
\text { themselves is congruent with } \\
\text { their conceptions of their ideal } \\
\text { selves during play (Lu, } \\
\text { Thompson, et al., 2012). }\end{array}$ \\
\hline
\end{tabular}

1 * Crutzen et al. (2016) hypothesized that competence is more important for influencing enjoyment, 2 even more so than autonomy and relatedness. 


\section{Table 2 (on next page)}

Affordances that facilitate participation in physical activity with respect to four different age categories (Kappen et al., 2017). 


\begin{tabular}{|l|l|l|}
\hline \multirow{2}{*}{$\begin{array}{l}\text { Age Category } \\
\text { (years old) }\end{array}$} & Motivate to participate & Continuation over the long-term \\
\hline $\mathbf{1 8 - 2 9}$ & $\begin{array}{l}\text { Badges, progression, goals } \\
\text { Calories, step-counters, } \\
\text { progression }\end{array}$ & Badges, goals, progression \\
\hline $\mathbf{3 0 - 6 4}$ & $\begin{array}{l}\text { Calories, distance travelled, } \\
\text { weight loss }\end{array}$ & Progression, step counters, time \\
\hline $\mathbf{6 5 +}$ & $\begin{array}{l}\text { Step-counters, distance travelled, } \\
\text { progression }\end{array}$ & Feedback progression, goals \\
\hline
\end{tabular}




\section{Table 3 (on next page)}

Differentiating gamified motivational affordances and feedback elements (Kappen et al., 2017). 


\begin{tabular}{|c|c|c|c|}
\hline \multirow{3}{*}{$\begin{array}{l}\text { Gamified } \\
\text { Motivational } \\
\text { Affordances }\end{array}$} & \multicolumn{3}{|c|}{ Motivational Elements } \\
\hline & Intrinsic & $\begin{array}{l}\text { Goals } \\
\text { Challenges } \\
\text { Progression } \\
\text { Achievements }\end{array}$ & $\begin{array}{l}\text { Choices/options } \\
\text { Quests } \\
\text { Social sharing }\end{array}$ \\
\hline & Extrinsic & \multicolumn{2}{|l|}{$\begin{array}{l}\text { Badges } \\
\text { Rewards } \\
\text { Points } \\
\text { Incentives } \\
\text { Leader boards }\end{array}$} \\
\hline $\begin{array}{l}\text { Feedback } \\
\text { Elements }\end{array}$ & \multicolumn{2}{|c|}{$\begin{array}{l}\text { Calorie tracker } \\
\text { Step-counters } \\
\text { Distance travelled } \\
\text { Daily notifications } \\
\text { Time spent } \\
\text { Heart rate }\end{array}$} & $\begin{array}{l}\text { Breathing rate } \\
\text { Sleep cycle } \\
\text { Sound inputs } \\
\text { Weight loss indicator } \\
\text { Physical form-checker } \\
\text { Gait/posture checker }\end{array}$ \\
\hline
\end{tabular}

1 


\section{Table 4 (on next page)}

Design guidelines for social exertion games (Mueller et al., 2009) . 


\begin{tabular}{|l|l|l|}
\hline 1 & Theme & Eesign Implications \\
\hline 2 & Metagaming & $\begin{array}{l}\text { Networked exertion games should support meaning } \\
\text { making through exertion by supporting various levels of } \\
\text { intensity of the game activity. }\end{array}$ \\
\hline 3 & $\begin{array}{l}\text { Metagaming is a social play phenomenon that refers to } \\
\text { the relationship of a game to elements outside of the } \\
\text { game and can be supported by allowing distributed } \\
\text { participants to retell the exertion activity with their body. }\end{array}$ \\
\hline 4 & Uncertainty & $\begin{array}{l}\text { To facilitate the synchronicity between players, offer } \\
\text { opportunities for kinesthetic movements. }\end{array}$ \\
\hline 5 & Breaking the rules & $\begin{array}{l}\text { Exertion can amplify the level of uncertainty afforded by } \\
\text { tangible objects. }\end{array}$ \\
\hline 6 & Awareness and exertion & $\begin{array}{l}\text { Players might reshape the game structure with their } \\
\text { actions, with positive and negative consequences. }\end{array}$ \\
\hline $\begin{array}{l}\text { A mismatch of awareness space and exertion space can } \\
\text { influence social play. The exertion space might be } \\
\text { larger than the game-play, as players move around } \\
\text { during and in-between games. }\end{array}$ \\
\hline
\end{tabular}




\section{Table 5 (on next page)}

An overview of selected studies examining the effectiveness of motivational strategies and approaches particularly for exergame adherence over the long-term. 


\begin{tabular}{|c|c|c|c|c|c|}
\hline \multicolumn{6}{|c|}{ Self Determination Theory } \\
\hline Reference & $\begin{array}{l}\text { Exergaming } \\
\text { Activity }\end{array}$ & $\begin{array}{l}\text { Activity } \\
\text { Duration }\end{array}$ & $\begin{array}{l}\text { Outcome } \\
\text { Measure }\end{array}$ & Results & Limitations \\
\hline $\begin{array}{l}\text { Limperos and } \\
\text { Schmierbach } \\
(2016)\end{array}$ & $\begin{array}{l}\text { Biggest loser - } \\
\text { skate or splash } \\
\text { (Nintendo Wii) }\end{array}$ & $\begin{array}{l}30 \\
\text { seconds } \\
\text { to } 10 \\
\text { minutes }\end{array}$ & $\begin{array}{l}\text { Enjoyment, } \\
\text { competence } \\
\text {, autonomy, } \\
\text { presence, } \\
\text { future } \\
\text { intention }\end{array}$ & $\begin{array}{l}\text { Better performance is } \\
\text { associated with great } \\
\text { levels of autonomy, } \\
\text { competence, } \\
\text { presence, enjoyment } \\
\text { and future intentions } \\
\text { to play. }\end{array}$ & $\begin{array}{l}\text { Sample } \\
\text { population: } \\
\text { College } \\
\text { students only; } \\
\text { not longitudinal } \\
\text { study. }\end{array}$ \\
\hline $\begin{array}{l}\text { Lin et al. } \\
(2012)\end{array}$ & $\begin{array}{l}\text { Walking, } \\
\text { running, } \\
\text { jumping }\end{array}$ & $\begin{array}{l}15 \\
\text { minutes }\end{array}$ & $\begin{array}{l}\text { Enjoyment, } \\
\text { effort for } \\
\text { gameplay, } \\
\text { motivation } \\
\text { for future } \\
\text { play, self- } \\
\text { efficacy }\end{array}$ & $\begin{array}{l}\text { Autonomy-supportive } \\
\text { and competence- } \\
\text { supportive game } \\
\text { features leads to } \\
\text { greater game } \\
\text { enjoyment and } \\
\text { motivation for future } \\
\text { play, whereas } \\
\text { satisfaction supportive } \\
\text { game features leads } \\
\text { to more energy } \\
\text { expenditure. }\end{array}$ & $\begin{array}{l}\text { Studied only } \\
\text { group of game } \\
\text { features, not } \\
\text { individual game } \\
\text { features. } \\
\text { Gamers only, } \\
\text { do not apply to } \\
\text { non-gamers. }\end{array}$ \\
\hline $\begin{array}{l}\text { Osorio et al. } \\
(2012)\end{array}$ & $\begin{array}{l}\text { Wii Sports, } \\
\text { DDR }\end{array}$ & $\mathrm{N} / \mathrm{A}$ & $\begin{array}{l}\text { Motivation } \\
\text { with respect } \\
\text { to SDT }\end{array}$ & $\begin{array}{l}\text { Enjoyment of social } \\
\text { interactions is a major } \\
\text { factor for playing } \\
\text { exergames. }\end{array}$ & $\begin{array}{l}\text { Small sample } \\
\text { size, university } \\
\text { students only. }\end{array}$ \\
\hline $\begin{array}{l}\text { Staiano at al. } \\
(2017)\end{array}$ & $\begin{array}{l}\text { Group-based } \\
\text { dance } \\
\text { exergames - } \\
\text { e.g.: Just } \\
\text { Dance }\end{array}$ & $\begin{array}{l}60 \text { minute } \\
\text { sessions, } \\
3 \text { times a } \\
\text { week for } \\
12 \text {-weeks }\end{array}$ & $\begin{array}{l}\text { Physical } \\
\text { Activity, self- } \\
\text { efficacy and } \\
\text { intrinsic } \\
\text { motivation }\end{array}$ & $\begin{array}{l}\text { Intervention group } \\
\text { reported higher levels } \\
\text { of intrinsic motivation } \\
\text { and improved self- } \\
\text { efficacy towards } \\
\text { physical activity } \\
\text { compared to the } \\
\text { control group. }\end{array}$ & $\begin{array}{l}\text { Limited to } \\
\text { obese female } \\
\text { adolescents. }\end{array}$ \\
\hline \multicolumn{6}{|c|}{ Gamification } \\
\hline Reference & $\begin{array}{l}\text { Exergaming } \\
\text { Activity }\end{array}$ & $\begin{array}{l}\text { Activity } \\
\text { Duration }\end{array}$ & $\begin{array}{l}\text { Outcome } \\
\text { Measure }\end{array}$ & Results & Limitations \\
\hline $\begin{array}{l}\text { Zhao et al. } \\
\text { (2017) }\end{array}$ & $\begin{array}{l}\text { Walking, } \\
\text { running, cycling }\end{array}$ & $\begin{array}{l}70 \text { days - } \\
\text { ranging } \\
\text { from } 4 \text { to } \\
6 \text { minutes } \\
\text { / session }\end{array}$ & $\begin{array}{l}\text { Time, satis- } \\
\text { faction, } \\
\text { encourage- } \\
\text { ment, } \\
\text { enjoyment }\end{array}$ & $\begin{array}{l}\text { Gradual release of } \\
\text { game features is } \\
\text { effective at keeping } \\
\text { players engaged. }\end{array}$ & $\begin{array}{l}\text { Sample } \\
\text { population: } \\
\text { university } \\
\text { students only; } \\
\text { environment: } \\
\text { indoors only. }\end{array}$ \\
\hline $\begin{array}{l}\text { Geelan et al. } \\
(2016)\end{array}$ & $\begin{array}{l}\text { Augmented } \\
\text { cycling and }\end{array}$ & $\begin{array}{l}30 \text { to } 90 \\
\text { minutes }\end{array}$ & $\begin{array}{l}\text { Energy } \\
\text { expenditure, }\end{array}$ & $\begin{array}{l}\text { Augmenting traditional } \\
\text { exercise equipment }\end{array}$ & $\begin{array}{l}\text { Small sample } \\
\text { size, short- }\end{array}$ \\
\hline
\end{tabular}




\begin{tabular}{|c|c|c|c|c|c|}
\hline & $\begin{array}{l}\text { rowing } \\
\text { exercises }\end{array}$ & & $\begin{array}{l}\text { physical } \\
\text { intensity, } \\
\text { duration and } \\
\text { enjoyment }\end{array}$ & $\begin{array}{l}\text { with gamified } \\
\text { elements can increase } \\
\text { the time spent } \\
\text { exercising, when } \\
\text { compared to non- } \\
\text { gamified exercise } \\
\text { equipment. }\end{array}$ & term. \\
\hline \multicolumn{6}{|c|}{ Competition and Cooperation } \\
\hline Reference & $\begin{array}{l}\text { Exergaming } \\
\text { Activity }\end{array}$ & $\begin{array}{l}\text { Activity } \\
\text { Duration }\end{array}$ & $\begin{array}{l}\text { Outcome } \\
\text { Measure }\end{array}$ & Results & Limitations \\
\hline $\begin{array}{l}\text { Staiano et al. } \\
(2015)\end{array}$ & $\begin{array}{l}\text { Nintendo Wii } \\
\text { sports games }\end{array}$ & $\begin{array}{l}\text { 20-weeks, } \\
30-60 \\
\text { minutes } \\
\text { per day }\end{array}$ & $\begin{array}{l}\text { Changes in } \\
\text { weight, peer } \\
\text { support, } \\
\text { self-efficacy, } \\
\text { and self- } \\
\text { esteem }\end{array}$ & $\begin{array}{l}\text { Cooperative game is } \\
\text { more effective than } \\
\text { competitive game for } \\
\text { weight loss. }\end{array}$ & $\begin{array}{l}\text { Studied only } \\
\text { children (15 to } \\
19 \text { years old); } \\
\text { small sample } \\
\text { size; only one } \\
\text { measure of } \\
\text { body adiposity } \\
\text { (weight). }\end{array}$ \\
\hline $\begin{array}{l}\text { Chan et al. } \\
\text { (2017) }\end{array}$ & Virtual bocce & 1 hour & $\begin{array}{l}\text { Enjoyment } \\
\text { and social } \\
\text { influence }\end{array}$ & $\begin{array}{l}\text { Competitive pairings } \\
\text { enjoyed competitive } \\
\text { game scenarios, } \\
\text { whereas cooperative } \\
\text { pairings enjoyed } \\
\text { cooperative game } \\
\text { scenarios. }\end{array}$ & $\begin{array}{l}\text { Small sample } \\
\text { size; } \\
\text { unbalanced } \\
\text { gender and } \\
\text { attitude } \\
\text { pairings. }\end{array}$ \\
\hline $\begin{array}{l}\text { Song et al. } \\
(2013)\end{array}$ & $\begin{array}{l}\text { Hula Hoop, a } \\
\text { Nintendo Wii } \\
\text { Fit program }\end{array}$ & $\begin{array}{l}10 \text { to } 18 \\
\text { minutes }\end{array}$ & $\begin{array}{l}\text { Intrinsic } \\
\text { motivation, } \\
\text { mood, } \\
\text { exercise } \\
\text { efficacy, } \\
\text { competitive- } \\
\text { ness, } \\
\text { expected } \\
\text { competence } \\
\text {, heart rate }\end{array}$ & $\begin{array}{l}\text { Highly-competitive } \\
\text { individuals enjoy } \\
\text { competitive game } \\
\text { settings, whereas non- } \\
\text { competitive individuals } \\
\text { do not enjoy } \\
\text { competitive game } \\
\text { settings. }\end{array}$ & $\begin{array}{l}\text { Short-term } \\
\text { study; } \\
\text { manipulation of } \\
\text { competition } \\
\text { context was } \\
\text { limited to } \\
\text { employing } \\
\text { external factors } \\
\text { (e.g.: a reward } \\
\text { system) rather } \\
\text { than changing } \\
\text { the exergame } \\
\text { content itself. }\end{array}$ \\
\hline $\begin{array}{l}\text { Shaw et al. } \\
(2016)\end{array}$ & Virtual cycling & $\begin{array}{l}\text { Three } 10 \\
\text { minute } \\
\text { exercise } \\
\text { sessions }\end{array}$ & $\begin{array}{l}\text { Enjoyment } \\
\text { and } \\
\text { motivation }\end{array}$ & $\begin{array}{l}\text { Competitive trainer } \\
\text { profile is motivating for } \\
\text { competitively inclined } \\
\text { individuals and } \\
\text { cooperative trainer is }\end{array}$ & $\begin{array}{l}\text { Small sample } \\
\text { size; short pilot } \\
\text { study. }\end{array}$ \\
\hline
\end{tabular}




\begin{tabular}{|c|c|c|c|c|c|}
\hline & & & & $\begin{array}{l}\text { more motivating for } \\
\text { goal oriented } \\
\text { individuals. }\end{array}$ & \\
\hline $\begin{array}{l}\text { Peng and } \\
\text { Crouse } \\
(2013)\end{array}$ & $\begin{array}{l}\text { Space-Pop } \\
\text { Mini game } \\
\text { (Kinect } \\
\text { Adventure) }\end{array}$ & $\begin{array}{l}2 \text { rounds - } \\
2 \text { minutes } \\
\text { and } 20 \\
\text { seconds. }\end{array}$ & $\begin{array}{l}\text { Enjoyment } \\
\text { and } \\
\text { motivation }\end{array}$ & $\begin{array}{l}\text { Parallel competition in } \\
\text { separate physical } \\
\text { spaces was the } \\
\text { optimal mode, leads to } \\
\text { both high enjoyment } \\
\text { and future play } \\
\text { motivation and high } \\
\text { physical intensity. }\end{array}$ & $\begin{array}{l}\text { Cooperation in } \\
\text { different } \\
\text { physical space } \\
\text { and } \\
\text { competition in } \\
\text { the same } \\
\text { physical space } \\
\text { was not } \\
\text { studied. }\end{array}$ \\
\hline \multicolumn{6}{|c|}{ Situational Interest } \\
\hline Reference & $\begin{array}{l}\text { Exergaming } \\
\text { Activity }\end{array}$ & $\begin{array}{l}\text { Activity } \\
\text { Duration }\end{array}$ & $\begin{array}{l}\text { Outcome } \\
\text { Measure }\end{array}$ & Results & Limitations \\
\hline $\begin{array}{l}\text { Pasco et al. } \\
(2017)\end{array}$ & $\begin{array}{l}\text { Stationary } \\
\text { biking }\end{array}$ & $\begin{array}{l}15 \\
\text { minutes }\end{array}$ & $\begin{array}{l}\text { Situational } \\
\text { interest and } \\
\text { physical } \\
\text { activity } \\
\text { levels }\end{array}$ & $\begin{array}{l}\text { A mobile application- } \\
\text { based exergame } \\
\text { capable of being } \\
\text { wirelessly paired to an } \\
\text { exercise bike can } \\
\text { promote light physical } \\
\text { activity, situational } \\
\text { interest, and other } \\
\text { important } \\
\text { psychological deter- } \\
\text { minants of physical } \\
\text { activity } \\
\text { participation compare- } \\
\text { ed to traditional biking } \\
\text { exercise. }\end{array}$ & $\begin{array}{l}\text { College } \\
\text { students only; } \\
\text { short-term } \\
\text { study; game } \\
\text { not challenging } \\
\text { enough for } \\
\text { highly fit } \\
\text { individuals. }\end{array}$ \\
\hline Sun (2013) & $\begin{array}{l}\text { Wii Sports - } \\
\text { dance games }\end{array}$ & $\begin{array}{l}\text { Twice a } \\
\text { week and } \\
\text { each } \\
\text { lesson } \\
\text { was } 30 \\
\text { min long }\end{array}$ & Enjoyment & $\begin{array}{l}\text { Prolonged exposure to } \\
\text { exergaming activities } \\
\text { may lead to decreased } \\
\text { perception of } \\
\text { situational interest, } \\
\text { which might lead to } \\
\text { lower motivation to } \\
\text { engage in exergames- } \\
\text { based physical activity } \\
\text { in the future. Boys } \\
\text { perceived exergaming } \\
\text { experience to be more } \\
\text { enjoyable than girls. } \\
\text { The use of a variety of } \\
\text { types of games might }\end{array}$ & $\begin{array}{l}\text { Results based } \\
\text { only on } \\
\text { children; } \\
\text { students were } \\
\text { required to } \\
\text { participate in } \\
\text { the exergaming } \\
\text { activities as } \\
\text { part of the } \\
\text { physical } \\
\text { education } \\
\text { program rather } \\
\text { than the } \\
\text { opportunity for } \\
\text { choice, and }\end{array}$ \\
\hline
\end{tabular}




\begin{tabular}{|c|c|c|c|c|c|}
\hline & & & & $\begin{array}{l}\text { result in enhanced } \\
\text { physical activity } \\
\text { intensity over time. }\end{array}$ & $\begin{array}{l}\text { thus, limited } \\
\text { autonomy. }\end{array}$ \\
\hline \multicolumn{6}{|c|}{ Social Interaction } \\
\hline Reference & $\begin{array}{l}\text { Exergaming } \\
\text { Activity }\end{array}$ & $\begin{array}{l}\text { Activity } \\
\text { Duration }\end{array}$ & $\begin{array}{l}\text { Outcome } \\
\text { Measure }\end{array}$ & Results & Limitations \\
\hline $\begin{array}{l}\text { Mueller et al. } \\
(2010)\end{array}$ & Table tennis & $\begin{array}{l}30-60 \\
\text { minutes }\end{array}$ & $\begin{array}{l}\text { Playing } \\
\text { experience }\end{array}$ & $\begin{array}{l}\text { Anticipation and } \\
\text { accountability are key } \\
\text { themes for the design } \\
\text { of social play specific } \\
\text { to exertion games. }\end{array}$ & $\begin{array}{l}\text { Limited to one } \\
\text { particular } \\
\text { game; based } \\
\text { only on } \\
\text { qualitative } \\
\text { observations } \\
\text { and analysis. }\end{array}$ \\
\hline $\begin{array}{l}\text { Park et al. } \\
(2012)\end{array}$ & $\begin{array}{l}\text { Running on a } \\
\text { treadmill }\end{array}$ & $\begin{array}{l}\text { Four } 20- \\
\text { minute } \\
\text { sessions } \\
\text { over two } \\
\text { weeks }\end{array}$ & $\begin{array}{l}\text { Enjoyment, } \\
\text { energy } \\
\text { expenditure, } \\
\text { competition } \\
\text { and } \\
\text { cooperation }\end{array}$ & $\begin{array}{l}\text { Cooperative play } \\
\text { increases social } \\
\text { interaction - there is a } \\
\text { relationship between } \\
\text { individual willingness, } \\
\text { derived intrinsically or } \\
\text { from the relation } \\
\text { between co-players, } \\
\text { and cooperation and } \\
\text { the cooperation } \\
\text { experience. }\end{array}$ & $\begin{array}{l}\text { Small sample } \\
\text { size; } 20 \text { to } 25 \\
\text { year olds only; } \\
\text { no features to } \\
\text { prevent } \\
\text { overexertion. }\end{array}$ \\
\hline $\begin{array}{l}\text { Kooiman and } \\
\text { Sheehan } \\
(2015)\end{array}$ & $\begin{array}{l}\text { Virtual bowling } \\
\text { and virtual } \\
\text { table tennis }\end{array}$ & $\begin{array}{l}40 \\
\text { minutes }\end{array}$ & $\begin{array}{l}\text { Intrinsic } \\
\text { motivation - } \\
\text { relatedness }\end{array}$ & $\begin{array}{l}\text { Motivation is high in } \\
\text { online and non-player } \\
\text { character exergaming } \\
\text { contexts. }\end{array}$ & $\begin{array}{l}\text { Results based } \\
\text { on children only } \\
\text { (ages 11-18) } \\
\text { and short-term. }\end{array}$ \\
\hline $\begin{array}{l}\text { Kaos, et al. } \\
(2019)\end{array}$ & $\begin{array}{l}\text { Networked, } \\
\text { cycling-based } \\
\text { exergame }\end{array}$ & 6 weeks & $\begin{array}{l}\text { Win rate, } \\
\text { time as } \\
\text { indicator of } \\
\text { engagement } \\
\text {, total } \\
\text { physical } \\
\text { activity and } \\
\text { belonging- } \\
\text { ness. }\end{array}$ & $\begin{array}{l}\text { Players who actively } \\
\text { engaged in social play } \\
\text { had significantly } \\
\text { higher exergame } \\
\text { adherence compared } \\
\text { to players who } \\
\text { primarily played alone. }\end{array}$ & $\begin{array}{l}\text { An exploratory } \\
\text { study based on } \\
\text { post-hoc } \\
\text { analysis of data } \\
\text { collected in an } \\
\text { earlier study } \\
\text { and lack of } \\
\text { personality } \\
\text { assessment. }\end{array}$ \\
\hline
\end{tabular}


Figure 1

Included study identification process.

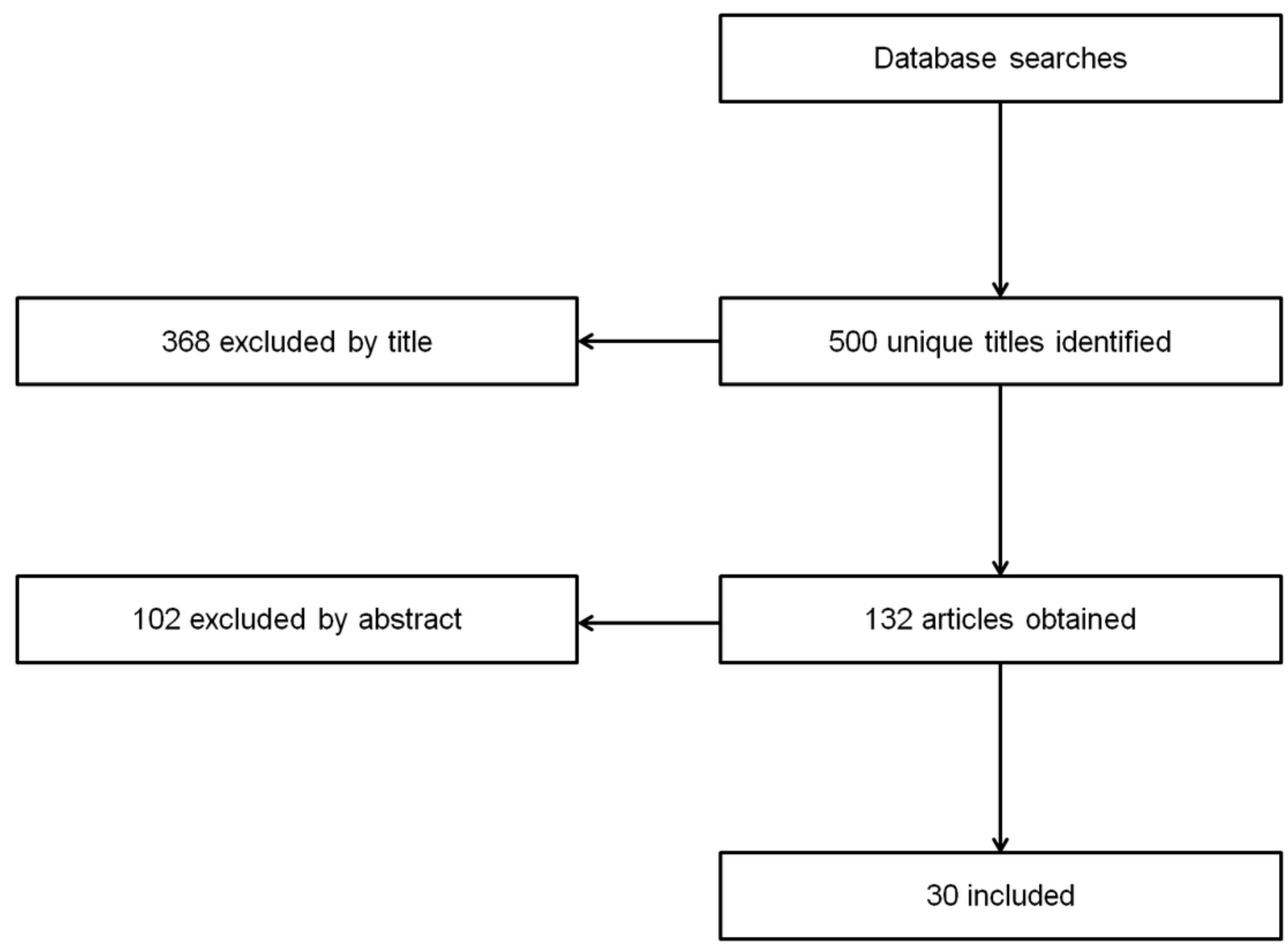


Figure 2

Model of the Flow zone in relation to challenge and skill level adapted from (Nakamura $\&$ Csikszentmihalyi, 2014).

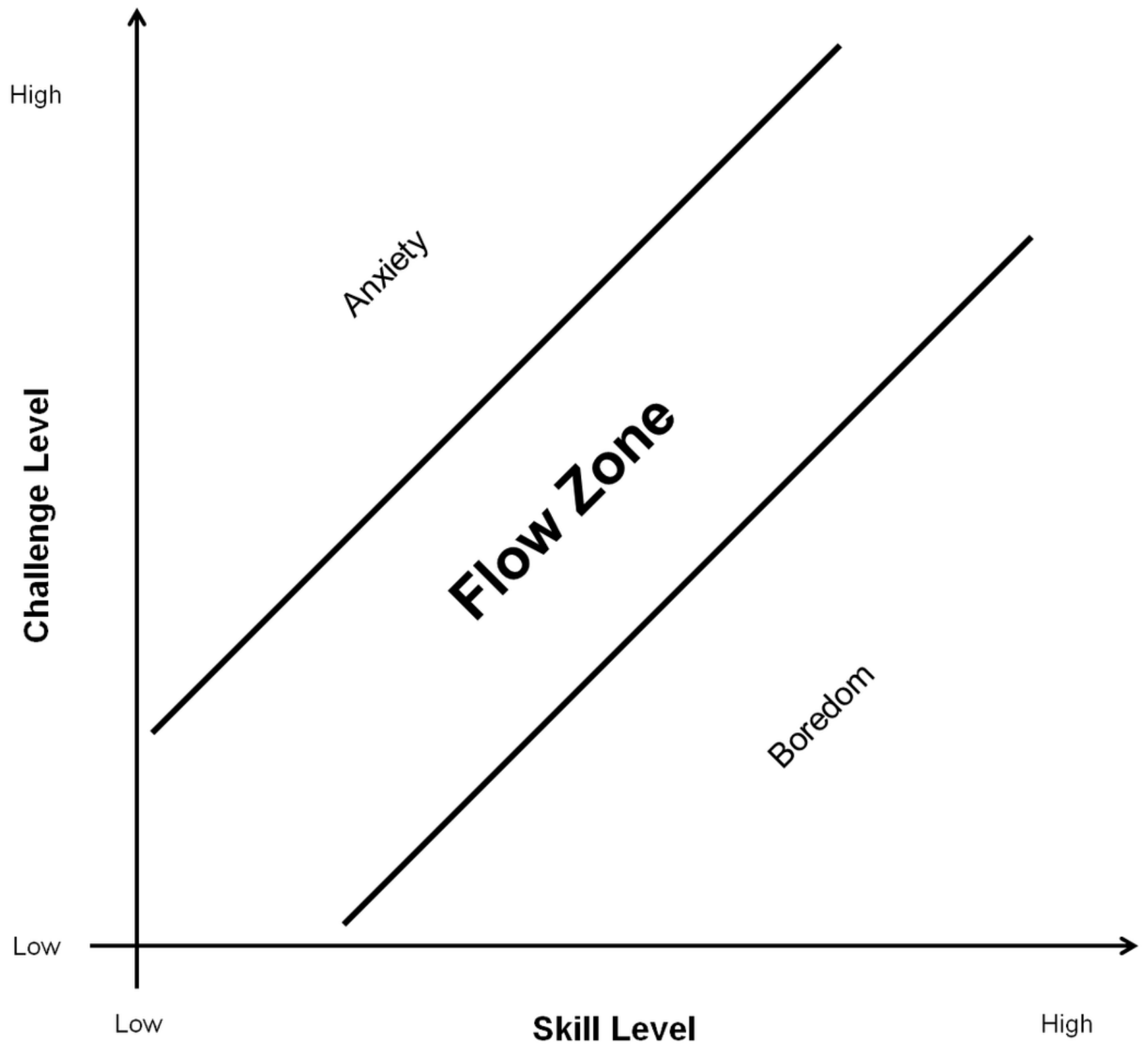


Figure 3

The Self-Determination Continuum adapted from Deci and Ryan (2009) SDT and the facilitation of intrinsic motivation, social development, and well-being.

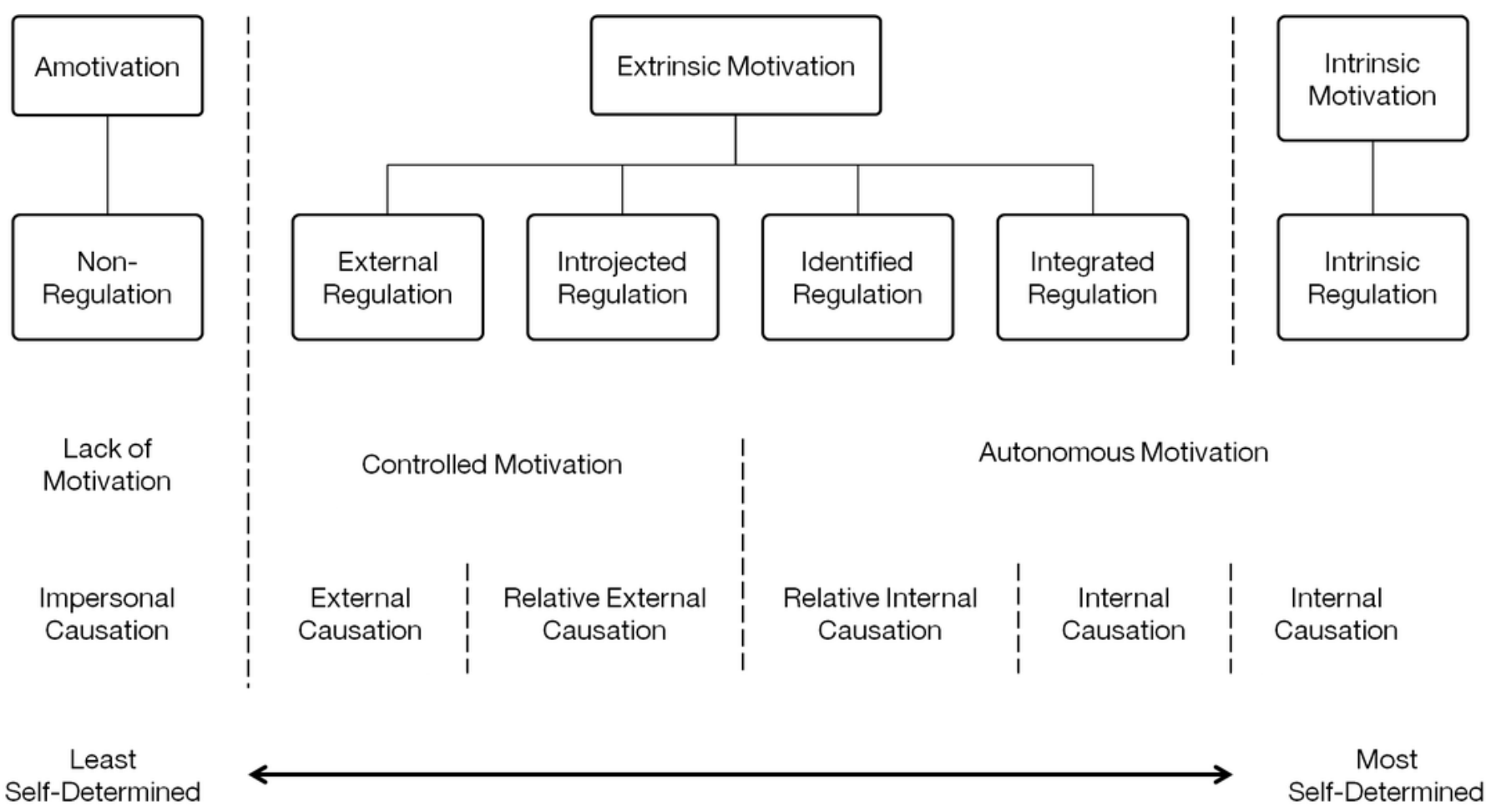


Figure 4

Relationship between SDT mediators, motivation, outcomes and motives (Boulos \& Yang, 2013).

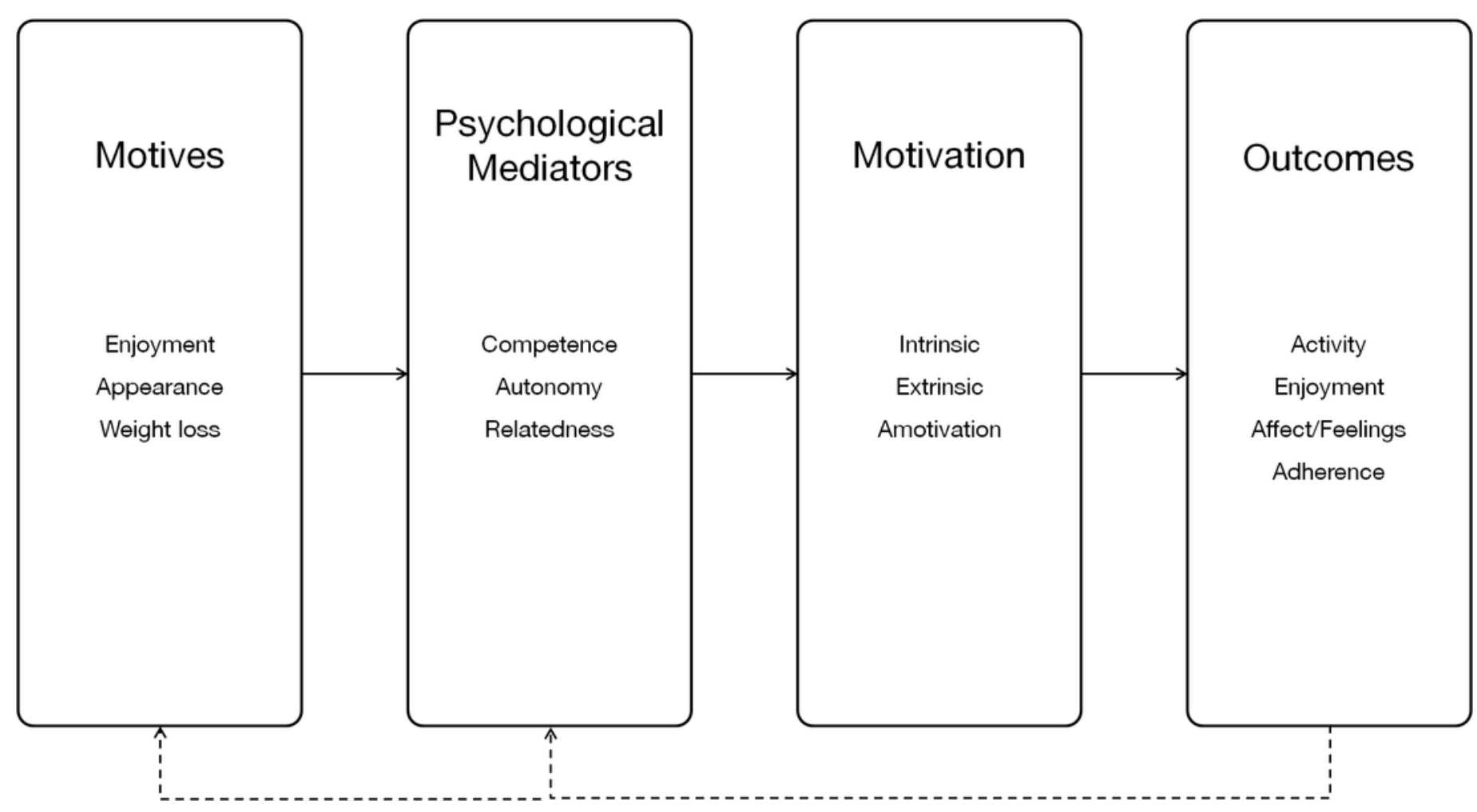

